\title{
Personality, Job Satisfaction and Health - The Mediating Influence of Affectivity
}

\author{
Justina A. V. Fischer and Alfonso Sousa-Poza ${ }^{\mathrm{b}}$
}

JEL-Classification: I18, I19, J28

Keywords: job satisfaction, health, SHARE, affectivity, work conditions

\section{Introduction}

Some research evidence suggests that the average workplace in several industrialized countries has become less stable and more insecure and that, in general, employment conditions have deteriorated (e.g., Schmidt, 1999; Swinnerton and Wial, 1995). Research also indicates that levels of job satisfaction have declined in the past decades (Hamermesh, 2001; Sousa-Poza and Sousa-Poza, 2003). Suggested reasons for this apparent trend include globalization, flexible employment, technological advancements (IT coverage), higher mobility, and in many countries, a deep recession in the 1990s. Even though to some extent such worries may be inflated (Wanner, 1999; Winkelmann and Zimmermann, 1998), the public at large is somewhat concerned that deteriorating job conditions and the resulting decline in job satisfaction may influence worker health. Thus, understanding the effects of job dissatisfaction (or stress) on an individual's

a (corresponding author), Dr., Department of Economics, Stockholm School of Economics, Sveavägen 65, SE-11383 Stockholm, Sweden and Thurgau Institute for Economics at the University of Konstanz, Hauptstrasse 90, CH-Kreuzlingen, Switzerland, Justina.Fischer@hhs.se or fischer@twi-kreuzlingen.ch

b Prof. Dr., Chair for Household and Consumer Economics, University of Hohenheim, Germany and Department of Economics, University of St. Gallen, Switzerland. E-mail: alfonso. sousa-poza@uni-hohenheim.de.

Acknowledgements: This study was realized using the data collected for the "Living in Switzerland Survey" compiled by the Swiss Household Panel (SHP) at the Universite de Neuchâtel, a project financed by the Swiss National Science Foundation (grant numbers 500453205/5004-57894/5004-67304/10FI11-103293). The authors would also like to thank the Swiss National Science Foundation for financial assistance (grant number 5004-69465). Justina Fischer thanks the London School of Economics (STICERD) for her generous hospitality and also acknowledges financing through a Marie Curie experienced researcher fellowship. 
health is important not only from a medical but also from an economic perspective. For example, while job satisfaction plays an important role at the employee level as a determinant of individual well-being, at the aggregate level, it equally affects worker productivity and retirement decisions, and ultimately, a society's economic prosperity (Faragher, Cass and Cooper, 2005; Henneberger and Sousa-Poza, 2007). Knowing how such components of subjective well-being affect individual health can thus provide valuable information on key policy issues like the rise in healthcare costs (especially in conjunction with mental illnesses) and the economic performance in many industrialized nations. Therefore, this study tests whether job satisfaction determines worker health.

Because of the topic's obvious relevance and importance, a large body of literature has already evolved on the relationship between employee job satisfaction and ill health (see Faragher, Cass and CoOper, 2005, for a metanalysis of over 450 studies). Arguments for the existence of such a link are many and varied. For example, recent research by organizational psychologists suggests that job satisfaction may have an indirect influence on health through employment conditions like workplace safety, lightening, quality of air, harassment, hierarchical position, responsibility, degree of automatization, work stress, and job security. In this case, the level of job satisfaction, by reflecting actual work conditions, serves only as a mediating, not as causal factor. Therefore, to remedy previous failure to identify a true causal relation, we also test for a direct impact of job satisfaction on worker health. We anticipate that such an impact may result from immeasurable and unobserved feelings of being in the right place and liking the job, and may even compensate for some harmful employment conditions. ${ }^{1}$

In addition, much of the vast literature on the subjective well-being-health link is hampered by methodological and design problems (SрестоR, 1997), including the use of cross-sectional data, unrepresentative datasets (e.g., $<30$ employees), unreliable measures of health status and calculation of simple correlation coefficients. Whereas simple correlations fail to take into account the impact of other potential determinants of health, regression analyses on cross-sectional data allow no conclusion of causality because of the potential endogeneity bias that health problems could affect individual well-being in the workplace (rather than vice versa). Moreover, as most studies only analyze specific populations, it is often impossible to generalize results to the entire working/active population. Finally, most studies rely on self-reports rather than objective health measures, so the finding that job satisfaction is conducive to subjective health may

1 For example, many scientists may have a high level of job satisfaction despite being underpaid, given the high workload, and under constant pressure to publish. 
be driven by "third factors" like working conditions or even personality traits like neuroticism, hardiness, extrovertism, or negative affectivity (BRIEF, BURKE, George, Robinson and Webster, 1988; Watson, Clark and Carey, 1988). For example, individuals high in negative affectivity ${ }^{2}$ tend, all else being equal, to be more discontented at work and equally more likely to assess their subjective health problems negatively.

Thus, this paper contributes to the research stream by examining the relationship between health and job satisfaction - a specific subjective measure of wellbeing - in a manner that remedies the shortcomings of previous research in four respects. First, our use of regression analysis partially eliminates the impact of other potential worker health determinants that may correlate with job satisfaction. Second, our use of panel data from the Swiss Household Panel (SHP) to test for causality between job satisfaction and health permits the lagging of job satisfaction, thereby enabling more convincing conclusions on causality. Third, employing objective health measures from the Survey of Health, Ageing and Retirement in Europe (SHARE) should yield more reliable results than using subjective measures of health alone, especially as both datasets contain a representative sample of the underlying population. Fourth, for both datasets, we explicitly test the 'third variable hypothesis' on working conditions, past health state, and affective state of mind. In addition, since the SHARE dataset includes only persons over 50 , we restrict the analyses for both datasets to this age group. ${ }^{3}$

The remainder of the paper is organized as follows. Section 2 discusses the empirical literature relating to job satisfaction and health. Section 3 introduces the model and data, and describes the estimation techniques. Section 4 discusses the estimation results and presents the robustness test, after which Section 5 summarizes the findings and concludes the paper.

2 The personality trait of negative affectivity reflects a person's tendency to experience negative emotions like anxiety or depression across a wide variety of situations (SPECTOR, 1997, p. 52).

3 Using a sample of older individuals also has methodological advantages. First, younger workers' job satisfaction levels tend to be more volatile than those of older workers but generally take a relatively short time to stabilize (i.e., for expectations and aspiration levels to adapt). This observation gives rise to the well-know phenomenon that job satisfaction is U-shaped with age (see Clark, Oswald and WARR, 1995). In contrast, the job satisfaction levels of older workers are less volatile and health status may be more sensitive to changes in job satisfaction, which justifies both the focus on older workers and the use of cross-sectional data. The former aspect is particularly important because older workers are generally less likely and less able than younger workers to change jobs when discontented. 


\section{Previous Research}

To date, economists have concentrated primarily on analyzing the determinants of job satisfaction (for an overview, see Sousa-Poza and Sousa-Poza, 2000b), which are influenced by many facets including gender (CLARK, 1997; CLARK and Oswald, 1996; Sousa-Poza and Sousa Poza, 2000a), age (Clark, Oswald and Warr, 1995), and education (Clark and Oswald, 1996; Tsang, Rumberger and Levin, 1991). This job satisfaction literature belongs to the broader field of happiness research, as represented by e.g. FreY and StUTZER (2000) and BJøRNSKov, Dreher and Fischer $(2007,2008)$. However, job satisfaction (or life satisfaction) as an explanatory variable appears infrequently in the economic literature, with the notable exception of research on the job satisfaction's effect on quitting behavior and retirement decisions. Nonetheless, limited recent empirical evidence does exist that current job satisfaction influences future labor turnover (see, e.g., Clark, 2001; Clark, Georgellis and Sanfey, 1998; Freeman, 1978).

In contrast, the relation between job satisfaction and health has been extensively studied by health scientists and organizational psychologists. For example, one comprehensive meta-analysis of 485 predominantly cross-sectional studies with mostly small sample sizes (although with a combined sample size of 267,995 individuals) based on self-report measures of both job satisfaction and health show an overall correlation across all health measures of 0.312 (FARAGHER, Cass and Cooper, 2005). Even though this analysis shows a strong correlation between job satisfaction and psychological problems like burnout $(r=0.478)$, selfesteem issues $(\mathrm{r}=0.429)$, depression $(\mathrm{r}=0.428)$, and anxiety $(\mathrm{r}=0.420)$; correlations with subjective evaluations of physical illness are much smaller $(r=0.287)$. Attempts to reveal a relationship between more objective measures of health and job satisfaction have been less fruitful (SрестоR, 1997, p. 67).

\section{Data and Methodology}

To analyze the relation between job satisfaction and health, we employ two different datasets: the Swiss Household Panel (SHP), and the Survey of Health, Ageing and Retirement in Europe (SHARE). The SHP, a longitudinal panel survey for which representative data for Switzerland have been gathered annually since 1999, covers the personal, economic, social, and political aspects of the respondent and her family. ${ }^{4}$ To estimate our model for Switzerland, we use four SHP

4 All interviews for the SHP are conducted using CATI. 
waves: the first wave of 1999, which contains current job satisfaction of that year on a 10-point scale (from 0, "not at all satisfied" to 10, "completely satisfied"), and the 2001 to 2003 waves, which include the subsequently observed health outcomes. The international cross-sectional dataset SHARE covers persons over 50 in 10 European countries ${ }^{5}$ for the year 2004. Similar in its theme coverage to SHP, this dataset also examines retirement, retirement pensions, health, and social life. In addition, the SHARE relates the job satisfaction variable, measured on a 4-point scale, to respondent satisfaction with the current job. ${ }^{6}$ Therefore, we use this dataset to estimate both an international cross-section (covering all 10 European countries) and a model for Switzerland exclusively.

To ensure comparability with the SHARE data, we restrict the SHP dataset to people aged 50 or older. ${ }^{7}$ Within that subset, we include only employed persons that answered the job-satisfaction question. Also deleted are observations with missing values on the remaining explanatory variables except for missing household income variables, which can be imputed. ${ }^{8}$ The final samples for both datasets are comparable in their age distribution: in the SHP (SHARE) sample, mean age is 59 (57), with a standard deviation of 5.5 (5.6) years. ' Additionally, most health measures are recoded so that the higher values represent a better health status (see Tables A1 and A2 of the Appendix for the actual variable definitions). In the SHARE dataset, equivalent income is based on the modified OECD equivalence scale, ${ }^{10}$ whereas the SHP uses the equivalence scale developed by the Swiss Conference for Public Assistance (SKOS). The SHP dataset

5 Austria, Germany, Sweden, the Netherlands, Spain, Italy, France, Denmark, Greece, and Switzerland.

6 This variable is measured by the prompt, "All things considered, I am satisfied with my job. Would you say you strongly agree, agree, disagree, or strongly disagree?"

7 In the case of the SHP, a person must have been 50 years or older in the 1999 wave to be retained in the sample.

8 The net equivalence income for the SHP is imputed using Stata's "impute" command (Stata 8.2). To take into account cultural differences within Switzerland, the analysis includes information on age, gender, type of occupation, type of household, and official household language. In the case of the SHARE data, imputed and PPP-adjusted household income values were provided by the research team that collected the data (see www.share-project.org).

9 Test-retest correlations cannot be computed for either dataset owing to their specific designs: each person was interviewed only once (per year, for the SHP).

10 This scale assigns a value of 1.0 to the first adult in the household and 0.5 for each subsequent adult, "adult" being defined as persons aged 15 or older. A child is given the value of 0.3 (OECD, 2004). Information on equivalence income is available in the SHP dataset but had to be deflated to the year 2000; equivalence income for the SHARE cross-section was calculated by the authors. 
has an unbalanced panel of about 2,500 observations for Switzerland, ${ }^{11}$ while the SHARE dataset has about 7,000 observations for Europe and about 470 for Switzerland. ${ }^{12}$

Both the SHARE and SHP datasets contain various self-report measures of health, which all form our set of dependent variables. In particular, they include assessments of individual general health status or improvement in health, as well as items relating to more specific health problems such as back problems, number of chronic diseases, or impediments to daily activities. Both datasets also provide information on personal recalls of hospital stays and doctor visits, which are both good indicators of more severe health problems among respondents. In addition, both datasets contain evaluations of a respondent's mental health, particularly with respect to the frequency and existence of depression in its various manifestations. As subjective measures of health, we employ all available health variables in the SHP data and then select comparable indicators in the SHARE data, thereby covering the widest range possible to ensure the robustness of our results.

Most important for this study, unlike the many surveys that contain only subjective health assessments, the SHARE dataset includes objective measures of interviewee's physical and intellectual abilities obtained using specific tests conducted by the interviewer at the time of the interview. Specifically, these tests measure the ability to walk or use both hands; proficiency in mathematics, recalling information, time orientation; and verbal fluency. ${ }^{13}$ Descriptive statistics for the corresponding regressors and regressands are given in Tables A3 and A4 of the Appendix.

We test the hypothesis that job satisfaction affects health status for both samples using the following model:

$$
Y_{t i}=\beta x_{t i}+\chi^{\prime} g_{t i}+\varepsilon_{t i} \text { with } \varepsilon_{t i}=v_{t i}+\varpi_{i}
$$

11 In a balanced panel, the identical individual is observed over a fixed number of periods. In an unbalanced panel, the number of observation periods varies by individual, the minimum being one period.

12 Because of different outcome variables, the number of missing observations varies among the various regression models.

13 Walking speed is the time that it takes a person to walk 2.5 meters. The strength of the respondent's handgrip was measured with a handgrip dynamometer, and the number of hands that could actively be used was also recorded. Mathematical proficiency was evaluated based on four simple calculations related to daily issues. Recall proficiency was tested using a list of ten words read aloud that respondents were first asked to recall immediately and then again after a delay. Time orientation was assessed by asking the interviewee to state the day of the week and the exact date. Finally, verbal fluency was measured by asking the respondent to name as many different animals as possible within one minute. For more details, see SHARE (2004). 
where $Y_{t i}$ denotes individual $i$ 's health state at time $t, x_{t i}$ is the variable of interest (i.e., job satisfaction), $g_{t i}$ is a vector of additional control variables, and $v_{t i}$ and $\varpi_{i}$ are the time-variant and time-invariant components, respectively, of the error term, $\varepsilon_{t i}$. As dependent variables, we employ a wide range of subjective and objective health measures, both general and more specific, both to ensure the robustness of our results and to differentiate between a general health impact and a specific health problem. The vector of additional control variables, although somewhat specific to the corresponding dataset, is identical for all estimated models. Based on typical empirical models of happiness, retirement, and health research, it not only includes information on gender, age, job type (according to Goldthorpe's class scheme), citizenship, household type, relative and mean equivalent income, voluntary activities, religion, physical activities, and community type but also integrates a Switzerland-specific cultural control variable (e.g. Frey and Stutzer, 2002; Dorn, Fischer, Kirchgässner and SousaPozA, 2008). ${ }^{14}$

In the case of the SHP panel data, which allows lagging of job satisfaction (the variable of interest), we estimate the following equation:

$$
Y_{t i}=\beta x_{1999 i}+\chi^{\prime} g_{t i}+v_{t i}+\varpi_{i}+t_{t} \text { with } t=2001 \text { through } 2003
$$

where the regressand, the error terms (individual and idiosyncratic), and most explanatory variables are from the 2001, 2002, and 2003 waves, measured contemporaneously with the health measure regressand $\left(Y_{t i}\right)$. The job satisfaction variable, however, is taken from the earlier 1999 wave to mitigate potential endogeneity. ${ }^{15}$ Please note that job satisfaction does not vary over time. Thus, for each interviewee we obtain an unbalanced panel in which the individual's health outcomes are observed for a maximum of three consecutive years. ${ }^{16} \mathrm{We}$ also include time dummies $\left(t_{t}\right)$ to account for shared patterns that vary over time but not between countries; for example, the state of the global economy, world climate, and global fears of terrorist attacks. The choice of different time points for the

14 Because of size discrepancies between the total SHARE dataset and its Swiss subsample, slight differences occur in the variable set and definitions. A list of the complete set of explanatory variables and explanands, as well as their data sources, is provided in Tables A1 and A2 in the Appendix.

15 To prevent endogeneity, the following regressors are also based on the 1999 wave: the measure of physical activity, the job type according to GOLDTHORPE's classification, and the dummy for voluntary work. All remaining exogenous variables are from 2001, 2002, or 2003. See also Table A2 of the Appendix.

16 See footnote 9 . 
variables reduces the endogeneity problem with respect to the health outcome variable. In addition, using a panel allows estimation of random effect models that take into account unobserved heterogeneity in the individual-specific residuals. Such a model requires the unobserved individual-specific and time-invariant characteristics to be uncorrelated with any of the explanatory variables. Please note that, owing to the time invariance of the job satisfaction variable, measured only at one point in time in 1999, a fixed effects estimation technique would be inappropriate. ${ }^{17}$

For the 2004 SHARE cross-section, the equation above is reduced as follows:

$$
Y_{t i}=\beta x_{t i}+\chi^{\prime} g_{t i}+\varepsilon_{t i} \text { with } t=2004
$$

where both the regressors $\left(x_{t i}, g_{t i}\right)$ and the regressand $\left(Y_{t i}\right)$ are measured at the same point in time. The disadvantages of such a model are not only that it fails to take into account unobserved heterogeneity between individuals but also that some explanatory variables are subject to a potential endogeneity that might bias the coefficient vector. The estimation techniques, selected according to the type of dependent variable, are OLS, logit, tobit, or ordered probit regression. When the estimation command allows, estimations are performed with heteroscedasticity-corrected robust standard errors. ${ }^{18}$

\section{Empirical Results}

\subsection{Subjective Measure of Physical Health}

Table 1 reports the estimated coefficients for various measures of subjective health, both the general state of health and specific health problems. This table also includes the marginal effects for any category for which a categorical regressand reflects the best health state, and for the outcome of 1 in the case of a dichotomous regressand. Results are given for the SHP, the whole SHARE dataset, and the Swiss subsample of the SHARE data.

17 For a study employing an individual fixed effects approach to the German Household Panel, see Fischer and Sousa-Poza (2008). This study, however, has the disadvantage that transmission channel effects of time-invariant personality traits cannot directly be analyzed.

18 Robust standard errors are applied to the estimation of the ordered probit, the logit, and the linear models but not to the tobit model. For the panel estimations, no such correction is available. 
In all three datasets, a significant increase in job satisfaction leads to a better subjective health status (at the 1 and 5 percent significance levels). For the SHARE dataset, this observation is made for two different health scales: one used in the U.S., the second in Europe. ${ }^{19}$ As suggested by previous studies, forming a dichotomous variable based on the categorical health-state variable for whether respondents consider their own health good yields a similar result for both Swiss and European samples. Most interesting, the impact of job satisfaction seems in terms of direction of influence and significance of coefficients - quite independent of whether it is lagged by between two to four years, as in the SHP, or measured contemporaneously, as in SHARE. Thus, we can conclude that job satisfaction does improve subjective health status and that, at least for a sample of persons aged 50 or older, simultaneity bias in prior findings based on crosssections alone is minimal.

Nonetheless, some proxies for a subjective evaluation of general health do not occur in all three datasets. For example, the SHP provides information on individual satisfaction with health and perceived health improvements within the last 12 months, whereas the SHARE dataset includes a question on life expectation. Measured according to all these alternative self-reported measures of health, workers who are more satisfied with their job (currently and in the past) also report a significantly better health status (at the 1 and 5 percent significance levels).

Table 2 presents the coefficients (and marginal effects) of the job satisfaction variable for more specific self-report health problems. Only two measures of specific health problems are comparable among the three datasets. First, in both the SHP panel and the full SHARE dataset, more satisfied people tend to have significantly fewer back pains (SHP) or other bone-related problems (SHARE) (at the 1 percent level). However, no such observation is made for the Swiss subsample of SHARE, even though the sign of the coefficient points in the predicted direction. Similarly, in both the overall SHARE and SHP datasets, those with higher job satisfaction also tend to report considerably fewer severe impediments to daily activities, with significances at the 1 percent level. However, in the Swiss subsample of SHARE, the coefficient of job satisfaction reaches significance only at the 10 percent level, even though it does have the expected sign.

19 In the SHARE questionnaire, the question on health state was posed at the beginning and end of the physical health part in both the U.S. and European version of the scale (the position of the question having been chosen randomly). Running regressions on the two subsamples (according to when each question was asked) does not change the results. 
Table 1: Subjective Measures of General Health State

\begin{tabular}{|c|c|c|c|c|c|c|c|}
\hline \multirow[b]{2}{*}{$\begin{array}{l}\text { Dependent } \\
\text { variables }\end{array}$} & \multicolumn{2}{|c|}{ SHP } & \multicolumn{2}{|c|}{$\begin{array}{c}\text { SHARE } \\
\text { intl. dataset }\end{array}$} & \multicolumn{2}{|c|}{$\begin{array}{c}\text { SHARE } \\
\text { Swiss subsample }\end{array}$} & \multirow[b]{2}{*}{$\begin{array}{l}\text { Estimation } \\
\text { technique }\end{array}$} \\
\hline & Coeff. & $\begin{array}{l}\text { Marg. } \\
\text { effect }\end{array}$ & Coeff. & $\begin{array}{l}\text { Marg. } \\
\text { effect }\end{array}$ & Coeff. & $\begin{array}{l}\text { Marg. } \\
\text { effect }\end{array}$ & \\
\hline $\begin{array}{l}\text { Health status } \\
\text { SHARE (EU) }\end{array}$ & $\begin{array}{l}0.068^{\dagger} \\
(2.41) \\
{[2474]}\end{array}$ & & $\begin{array}{c}0.244^{*} \\
(11.46) \\
{[7042]}\end{array}$ & $\begin{array}{c}0.085^{*} \\
(11.40)\end{array}$ & $\begin{array}{l}0.262^{*} \\
(4.63) \\
{[472]}\end{array}$ & $\begin{array}{l}0.098^{*} \\
(4.79)\end{array}$ & $\begin{array}{l}\text { Ordered } \\
\text { probit }\end{array}$ \\
\hline $\begin{array}{l}\text { Health status } \\
\text { SHARE (US) }\end{array}$ & & & $\begin{array}{c}0.261^{*} \\
(13.01) \\
{[7042]}\end{array}$ & $\begin{array}{c}0.075^{*} \\
(11.60)\end{array}$ & $\begin{array}{l}0.213^{*} \\
(3.86) \\
{[472]}\end{array}$ & $\begin{array}{l}0.081^{*} \\
(3.64)\end{array}$ & $\begin{array}{l}\text { Ordered } \\
\text { probit }\end{array}$ \\
\hline $\begin{array}{l}\text { Good health } \\
\text { SHARE (EU) }\end{array}$ & $\begin{array}{l}0.144^{\dagger} \\
(2.07) \\
{[2474]}\end{array}$ & & $\begin{array}{l}0.409^{*} \\
(8.83) \\
{[7043]}\end{array}$ & $\begin{array}{l}0.064^{*} \\
(6.60)\end{array}$ & $\begin{array}{l}0.508^{*} \\
(3.18) \\
{[472]}\end{array}$ & $\begin{array}{c}0.007 \\
(1.55)\end{array}$ & Logit \\
\hline $\begin{array}{l}\text { Good health } \\
\text { SHARE (US) }\end{array}$ & & & $\begin{array}{c}0.471^{*} \\
(11.54) \\
{[7043]}\end{array}$ & $\begin{array}{c}0.118^{*} \\
(11.62)\end{array}$ & $\begin{array}{l}0.431^{*} \\
(4.01) \\
{[472]}\end{array}$ & $\begin{array}{l}0.083^{*} \\
(4.03)\end{array}$ & Logit \\
\hline $\begin{array}{l}\text { Satisfaction with } \\
\text { health status }\end{array}$ & $\begin{array}{l}0.126^{*} \\
(3.99) \\
{[2474]}\end{array}$ & & & & & & $\begin{array}{l}\text { Ordered } \\
\text { probit }\end{array}$ \\
\hline $\begin{array}{l}\text { Health } \\
\text { improvement }\end{array}$ & $\begin{array}{l}0.047^{\dagger} \\
(2.24) \\
{[2473]}\end{array}$ & & & & & & $\begin{array}{l}\text { Ordered } \\
\text { probit }\end{array}$ \\
\hline $\begin{array}{l}\text { Subjective life } \\
\text { expectancy }\end{array}$ & & & $\begin{array}{l}4.180^{*} \\
(7.22) \\
{[6719]}\end{array}$ & & $\begin{array}{l}3.406^{\dagger} \\
(2.28) \\
{[453]}\end{array}$ & & Tobit \\
\hline
\end{tabular}

Notes: RE ordered probit, RE logit, RE tobit, or GLS regression (SHP). Ordered probit, logit, tobit, and OLS regression (SHARE). All estimations are performed with robust standard errors where technically possible. ${ }^{*},{ }^{\dagger}$, and ${ }^{*}$ indicate significance at the $1 \%, 5 \%$, and $10 \%$ levels, respectively. Absolute values of t-/z-statistics are reported in round brackets and number of observations, in square brackets. Predicted outcome for a dichotomous variable is 1 and for a categorical variable, the lowest or highest category that reflects the best health state. Where possible, marginal effects are calculated at the median value of the control variables of all observations retained in the regression sample. 
Table 2: Subjective Measures of Specific Health Problems

\begin{tabular}{|c|c|c|c|c|c|c|c|}
\hline \multirow[b]{2}{*}{$\begin{array}{l}\text { Dependent } \\
\text { variables }\end{array}$} & \multicolumn{2}{|c|}{ SHP } & \multicolumn{2}{|c|}{$\begin{array}{c}\text { SHARE } \\
\text { intl. dataset }\end{array}$} & \multicolumn{2}{|c|}{$\begin{array}{c}\text { SHARE } \\
\text { Swiss subsample }\end{array}$} & \multirow[b]{2}{*}{$\begin{array}{l}\text { Estimation } \\
\text { technique }\end{array}$} \\
\hline & Coeff. & $\begin{array}{l}\text { Marg. } \\
\text { effects }\end{array}$ & Coeff. & $\begin{array}{l}\text { Marg. } \\
\text { effect }\end{array}$ & Coeff. & $\begin{array}{l}\text { Marg. } \\
\text { effect }\end{array}$ & \\
\hline $\begin{array}{l}\text { Problems with the } \\
\text { back (SHP), hips, } \\
\text { or knees (SHARE) }\end{array}$ & $\begin{array}{l}-0.199^{*} \\
(2.96) \\
{[2474]}\end{array}$ & & $\begin{array}{l}-0.221^{*} \\
(5.82) \\
{[7043]}\end{array}$ & $\begin{array}{c}-0.054^{*} \\
(5.82)\end{array}$ & $\begin{array}{c}-0.138 \\
(1.32) \\
{[472]}\end{array}$ & $\begin{array}{r}-0.027 \\
(1.38)\end{array}$ & Logit \\
\hline $\begin{array}{l}\text { Impediments to } \\
\text { daily activities }\end{array}$ & $\begin{array}{l}-0.094^{*} \\
(3.07) \\
{[2470]}\end{array}$ & & $\begin{array}{l}-0.186^{*} \\
(7.55) \\
{[7042]}\end{array}$ & $\begin{array}{c}-0.067^{*} \\
(7.13)\end{array}$ & $\begin{array}{c}-0.203^{\ddagger} \\
(1.72) \\
{[472]}\end{array}$ & $\begin{array}{c}-0.021^{\ddagger} \\
(1.75)\end{array}$ & $\begin{array}{l}\text { Ordered } \\
\text { probit }\end{array}$ \\
\hline Headaches & $\begin{array}{l}-0.060 \\
(0.73) \\
{[2473]}\end{array}$ & & & & & & Logit \\
\hline $\begin{array}{l}\text { Number of days } \\
\text { with health } \\
\text { problems }\end{array}$ & $\begin{array}{l}-1.209^{\dagger} \\
(2.47) \\
{[2451]}\end{array}$ & & & & & & Tobit \\
\hline Long-term illnesses & & & $\begin{array}{l}-0.218^{*} \\
(5.57) \\
{[7043]}\end{array}$ & $\begin{array}{c}-0.049^{*} \\
(5.31)\end{array}$ & $\begin{array}{l}0.018 \\
(0.17) \\
{[472]}\end{array}$ & $\begin{array}{l}0.004 \\
(0.17)\end{array}$ & Logit \\
\hline $\begin{array}{l}\text { Number of chronic } \\
\text { diseases }\end{array}$ & & & $\begin{array}{l}-0.087^{*} \\
(4.31) \\
{[7037]}\end{array}$ & $\begin{array}{c}-0.034^{*} \\
(4.33)\end{array}$ & $\begin{array}{c}-0.144 \\
(1.61) \\
{[472]}\end{array}$ & & $\begin{array}{l}\text { Ordered } \\
\text { probit }\end{array}$ \\
\hline $\begin{array}{l}\text { Number of } \\
\text { symptoms }\end{array}$ & & & $\begin{array}{l}-0.159^{*} \\
(7.99) \\
{[7042]}\end{array}$ & $\begin{array}{c}-0.063^{*} \\
(8.06)\end{array}$ & $\begin{array}{l}-0.142^{\dagger} \\
(2.54) \\
{[472]}\end{array}$ & $\begin{array}{l}-0.051^{*} \\
(2.68)\end{array}$ & $\begin{array}{l}\text { Ordered } \\
\text { probit }\end{array}$ \\
\hline $\begin{array}{l}\text { Mobility assess- } \\
\text { ment: number } \\
\text { of limitations }\end{array}$ & & & $\begin{array}{l}-0.442^{*} \\
(6.71) \\
{[7039]}\end{array}$ & & $\begin{array}{l}-0.435^{*} \\
(2.66) \\
{[472]}\end{array}$ & & Tobit \\
\hline $\begin{array}{l}\text { Daily activities: } \\
\text { number of } \\
\text { limitations }\end{array}$ & & & $\begin{array}{l}-0.312^{\dagger} \\
(2.01) \\
{[7040]}\end{array}$ & & $\begin{array}{c}-0.396 \\
(1.25) \\
{[472]}\end{array}$ & & Tobit \\
\hline $\begin{array}{l}\text { Daily instrumental } \\
\text { activities: number } \\
\text { of limitations }\end{array}$ & & & $\begin{array}{c}-0.164 \\
(1.49) \\
{[7040]}\end{array}$ & & $\begin{array}{c}-0.350 \\
(1.09) \\
{[472]}\end{array}$ & & Tobit \\
\hline
\end{tabular}

Notes: RE ordered probit, RE logit, RE tobit, or GLS regression (SHP). Ordered probit, logit, tobit, and OLS regression (SHARE). All estimations are performed with robust standard errors where technically possible. ${ }^{*},{ }^{\dagger}$, and ${ }^{\ddagger}$ indicate significance at the $1 \%, 5 \%$, and $10 \%$ levels, respectively. Absolute values of $\mathrm{t}-\mathrm{z}$-statistics are reported in round brackets and number of observations, in square brackets. Predicted outcome for a dichotomous variable is 1 and for categorical variables, the lowest or highest category that reflects the best health state. Where possible, marginal effects are calculated at the median value of the control variables of all observations retained in the regression sample. 
In the full SHARE sample, a higher level of job satisfaction also decreases the probability of long-term illness, the number of chronic diseases, the number of disease symptoms, and the number of limitations on physical mobility. Interestingly, job satisfaction appears to negatively affect the number of limitations on daily activities (at the 5 percent level) but not instrumental activities. ${ }^{20}$ Thus, persons with a higher level of job satisfaction seemingly enjoy more robust health, which permits daily living without external aid. Similarly, in the SHP dataset, an increase in job satisfaction significantly reduces the number of days with health problems (at the 5 percent level).

In many instances, the coefficients of job satisfaction in the Swiss subsample are not significant at conventional levels, even though the model specification is the same as for the general health satisfaction variable given in Table 1. The exceptions are the regressands for number of symptoms and number of mobility limitations (at the 5 and 10 percent levels, respectively). In both these cases, consistent with the results for the full SHARE dataset, an increase in job satisfaction decreases the probability of such (self-reported) health problems.

Table 3 displays the results for the mental health measures, particularly those relating to depression. Respondents in all datasets were questioned on the occurrence of both depression and the symptoms often used as proxies for depression, including sleeping problems, lack of energy, and feelings of weakness. In general, the outcomes are similar for both the SHP and the international SHARE dataset. For all measures of depression, a higher level of job satisfaction is associated with a lower frequency of symptoms or a lower likelihood of being depressed. As observed earlier, almost no significant coefficients exist in the Swiss subsample of the SHARE data, even though the signs point in the predicted direction. Nonetheless, in the Swiss subsample, the coefficient on job satisfaction is significant at the 10 percent level for sleeping problems, and the coefficient for the variable capturing frequency of depression narrowly misses the 10 percent significance level. Again, job satisfaction appears to influence mental health in the same way in Switzerland as in other Western European countries.

As regards self-reported contacts with the healthcare system, Table 4 reports estimation results for contacts with doctors and hospitals, which may proxy the presence of severe illness. In the SHP, job satisfaction has a weak impact

20 The two types of limitations differ in that the first relates to performing basic activities like eating, dressing, and washing, while the second relates to those activities that make the latter possible (e.g., cooking and shopping). Persons with the first type of limitation must be sent to nursing homes, whereas persons with the second type can continue an independent life with some external aid. 
Table 3: Subjective Measures of Mental Health (Depression)

\begin{tabular}{|c|c|c|c|c|c|c|c|}
\hline \multirow[b]{2}{*}{$\begin{array}{l}\text { Dependent } \\
\text { variables }\end{array}$} & \multicolumn{2}{|c|}{ SHP } & \multicolumn{2}{|c|}{$\begin{array}{c}\text { SHARE } \\
\text { intl. dataset }\end{array}$} & \multicolumn{2}{|c|}{$\begin{array}{c}\text { SHARE } \\
\text { Swiss subsample }\end{array}$} & \multirow[b]{2}{*}{$\begin{array}{l}\text { Estimation } \\
\text { technique }\end{array}$} \\
\hline & Coeff. & $\begin{array}{l}\text { Marg. } \\
\text { effects }\end{array}$ & Coeff. & $\begin{array}{l}\text { Marg. } \\
\text { effect }\end{array}$ & Coeff. & $\begin{array}{l}\text { Marg. } \\
\text { effect }\end{array}$ & \\
\hline $\begin{array}{l}\text { Frequency of } \\
\text { depression }\end{array}$ & $\begin{array}{l}-0.156^{*} \\
(4.65) \\
{[2474]}\end{array}$ & & $\begin{array}{c}-0.242^{*} \\
(12.01) \\
{[6993]}\end{array}$ & $\begin{array}{l}-0.094^{*} \\
(12.13)\end{array}$ & $\begin{array}{c}-0.088 \\
(1.64) \\
{[472]}\end{array}$ & $\begin{array}{l}-0.035^{\ddagger} \\
(1.65)\end{array}$ & $\begin{array}{l}\text { Ordered } \\
\text { probit }\end{array}$ \\
\hline $\begin{array}{l}\text { Frequency of } \\
\text { energy (SHP) }\end{array}$ & $\begin{array}{l}0.190^{*} \\
(7.52) \\
{[2473]}\end{array}$ & & & & & & $\begin{array}{l}\text { Ordered } \\
\text { probit }\end{array}$ \\
\hline $\begin{array}{l}\text { Lack of energy } \\
\text { (SHARE) }\end{array}$ & & & $\begin{array}{l}-0.354^{*} \\
(8.09) \\
{[7015]}\end{array}$ & $\begin{array}{l}-0.060^{*} \\
(6.49)\end{array}$ & $\begin{array}{c}-0.164 \\
(1.29) \\
{[472]}\end{array}$ & $\begin{array}{c}-0.016 \\
(1.41)\end{array}$ & Logit \\
\hline Sleeping problems ${ }^{a}$ & $\begin{array}{l}-0.172^{\ddagger} \\
(1.91) \\
{[2474]}\end{array}$ & & $\begin{array}{l}-0.288^{*} \\
(5.49) \\
{[7043]}\end{array}$ & $\begin{array}{l}-0.025^{*} \\
(4.11)\end{array}$ & $\begin{array}{c}-0.260^{\ddagger} \\
(1.71) \\
{[472]}\end{array}$ & $\begin{array}{c}-0.014 \\
(1.69)\end{array}$ & Logit \\
\hline $\begin{array}{l}\text { Feeling of } \\
\text { weakness }\end{array}$ & $\begin{array}{l}-0.325^{*} \\
(4.78) \\
{[2474]}\end{array}$ & & $\begin{array}{l}-0.200^{\dagger} \\
(2.28) \\
{[7043]}\end{array}$ & $\begin{array}{l}-0.005^{\ddagger} \\
(1.85)\end{array}$ & $\begin{array}{r}\text { Insu } \\
\text { num } \\
\text { obse }\end{array}$ & $\begin{array}{l}\text { icient } \\
\text { ser of } \\
\text { rations }\end{array}$ & Logit \\
\hline
\end{tabular}

Notes: RE ordered probit, RE logit, RE tobit, or GLS regression (SHP). Ordered probit, logit, tobit, and OLS regression (SHARE). All estimations are performed with robust standard errors where technically possible. ${ }^{*},{ }^{\dagger}$, and ${ }^{\ddagger}$ indicate significance at the $1 \%, 5 \%$, and $10 \%$ levels, respectively. Absolute values of $\mathrm{t}-\mathrm{z}$-statistics are reported in round brackets and number of observations, in square brackets. Predicted outcome for a dichotomous variable is 1 and for categorical variables, the lowest or highest category that reflects the best health state. Where possible, marginal effects are calculated at the median value of the control variables of all observations retained in the regression sample.

a In the SHARE dataset, the question on sleeping problems was posed twice: once as part of the mental health questionnaire and once as part of the physical health assessment. The results for both variables are similar. The results reported here are from the physical health questionnaire.

on health improvement as measured by the number of times medical advice was sought (at the 10 percent level). However, this effect is stronger in the full SHARE sample (at the 1 percent level), in which a higher level of job satisfaction also appears to decrease the likelihood, number, and length of stay in hospitals (two at the 10 percent and one at the 1 percent level, respectively). Such exact measures were unavailable in the SHP, but the simple dichotomous measure "likelihood of consultation with a doctor" seems unaffected by job satisfaction. For the Swiss SHARE subsample, we once again detect only insignificant coefficients for the various regressands, except for the number of times a doctor 
was consulted, whose coefficient shows the expected sign and just misses significance at the 10 percent level.

To conclude, in European countries overall, more satisfied persons aged 50 or older tend to make less use of the healthcare system, a result that is not so apparent in Switzerland. ${ }^{21}$ Although this finding of lesser contact with the healthcare system seemingly supports a health-improving impact of job satisfaction, these results still rely on self-reported measures that might be affected by the respondent's affective state.

Table 4: Subjective Measures of Health Status: Contact with Doctors or Hospitals

\begin{tabular}{|c|c|c|c|c|c|c|c|}
\hline \multirow[b]{2}{*}{$\begin{array}{l}\text { Dependent } \\
\text { variables }\end{array}$} & \multicolumn{2}{|c|}{ SHP } & \multicolumn{2}{|c|}{$\begin{array}{l}\text { SHARE } \\
\text { intl. dataset }\end{array}$} & \multicolumn{2}{|c|}{$\begin{array}{c}\text { SHARE } \\
\text { Swiss subsample }\end{array}$} & \multirow[b]{2}{*}{$\begin{array}{l}\text { Estimation } \\
\text { technique }\end{array}$} \\
\hline & Coeff. & $\begin{array}{l}\text { Marg. } \\
\text { effects }\end{array}$ & Coeff. & $\begin{array}{l}\text { Marg. } \\
\text { effects }\end{array}$ & Coeff. & $\begin{array}{l}\text { Marg. } \\
\text { effects }\end{array}$ & \\
\hline $\begin{array}{l}\text { Consultation } \\
\text { with doctor }\end{array}$ & $\begin{array}{l}0.003 \\
(0.05) \\
{[2472]}\end{array}$ & & & & & & Logit \\
\hline $\begin{array}{l}\text { Number of times } \\
\text { a doctor consulted }\end{array}$ & $\begin{array}{l}-0.432^{\ddagger} \\
(1.82) \\
{[2315]}\end{array}$ & & $\begin{array}{l}-1.154^{*} \\
(5.19) \\
{[7036]}\end{array}$ & & $\begin{array}{c}-1.200 \\
(1.61) \\
{[472]}\end{array}$ & & Tobit \\
\hline $\begin{array}{l}\text { Hospital stays } \\
\text { during last } \\
12 \text { months }\end{array}$ & & & $\begin{array}{c}-0.113^{\ddagger} \\
(1.66) \\
{[7043]}\end{array}$ & $\begin{array}{c}-0.007 \\
(1.56)\end{array}$ & $\begin{array}{r}0.065 \\
(0.39) \\
{[472]}\end{array}$ & $\begin{array}{c}0.004 \\
(0.36)\end{array}$ & Logit \\
\hline Times hospitalized & & & $\begin{array}{l}-0.153^{\ddagger} \\
(1.76) \\
{[7043]}\end{array}$ & & $\begin{array}{c}0.141 \\
(0.65) \\
{[472]}\end{array}$ & & Tobit \\
\hline $\begin{array}{l}\text { Total nights in } \\
\text { hospital }\end{array}$ & & & $\begin{array}{l}-2.790^{*} \\
(2.80) \\
{[7041]}\end{array}$ & & $\begin{array}{l}1.252 \\
(0.50) \\
{[472]}\end{array}$ & & Tobit \\
\hline
\end{tabular}

Notes: RE ordered probit, RE logit, RE tobit, or GLS regression (SHP). Ordered probit, logit, tobit, and OLS regression (SHARE). All estimations are performed with robust standard errors where technically possible. ${ }^{*},{ }^{\dagger}$, and ${ }^{\ddagger}$ indicate significance at the $1 \%, 5 \%$, and $10 \%$ levels, respectively. Absolute values of $\mathrm{t}-\mathrm{z}$-statistics are reported in round brackets and number of observations, in square brackets. Predicted outcome for a dichotomous variable is 1 and for categorical variables, the lowest or highest category that reflects the best health state. Where possible, marginal effects are calculated at the median value of the control variables of all observations retained in the regression sample.

21 One possible explanation might be the difference in personal healthcare financing. In Switzerland, because the insured must pay a high fixed excess charge, the incentive to reduce costly contacts with the healthcare system may be equally strong for satisfied and dissatisfied persons. 


\subsection{Objective Measures of Health}

These results, based on subjective measures of health, correspond well to the findings of previous studies. Moreover, the fact that we obtain very significant effects for job satisfaction on health even in a panel setting implies that simultaneity bias is minimal in cross-sections. Nonetheless, because this analysis is based only on self-reports of both job satisfaction and symptoms that could be biased by affective disposition (i.e., people satisfied with their jobs may systematically view their health state more positively), the results imply no true causal link between job satisfaction and health. Therefore, the relation between job satisfaction and health must be tested using objective (more direct) measures of health, which the SHARE dataset provides.

The results for the objective health measures from the SHARE dataset, including the measures of both physical and intellectual ability, are reported in Table 5. The tests of physical ability include walking speed, maximum handgrip strength, hand dexterity, and Body Mass Index (BMI) ranking. According to SHARE (2004, p. 38 ff.), these tests of physical ability serve not only as indicators of current age and extent of impairment in daily activities, but equally as predictors of future healthcare system use and expected mortality among older persons. For example, a weak handgrip prevents people from raising their own body weight, and a slow walking speed indicates a higher probability of falling and related injuries (SHARE, 2004, p. 44). The regressions outcomes indicate that job satisfaction apparently has no effect on any measure of physical health, a finding that holds true for both the full SHARE sample and the Swiss subsample. Thus, we conclude that the health-improving impact of job satisfaction found in the subjective health assessments (see Tables 1 through 4), are not mirrored by the corresponding objective measures of physical health (Table 5).

Most interesting, however, are the estimation results for objective measures of intellectual ability, which include mathematical performance, recall ability, time orientation, and verbal fluency (Table 5). In the full SHARE sample, we observe that a higher level of job satisfaction substantially increases mathematical performance, immediate and delayed recall ability, and verbal fluency (all at the 1 percent level), although no impact is apparent on time orientation. This finding is generally corroborated by the estimation results for the Swiss subsample, particularly for mathematical performance and immediate recall of ten words.

Based on the interpretations of the used measures given in SHARE (2004, p. $36 \mathrm{ff}$.), people with higher job satisfaction show better verbal learning abilities but no better general memory (as measured by the question on time and date recollection). In addition, the brains of such respondents apparently work more 
Table 5: Measures of Objective Health Status for the SHARE Dataset

\begin{tabular}{|c|c|c|c|c|c|}
\hline \multirow[b]{2}{*}{$\begin{array}{l}\text { Dependent } \\
\text { variables }\end{array}$} & \multicolumn{2}{|c|}{ SHARE int. dataset } & \multicolumn{2}{|c|}{ SHARE Swiss subsample } & \multirow[b]{2}{*}{$\begin{array}{l}\text { Estimation } \\
\text { technique }\end{array}$} \\
\hline & Coeff. & $\begin{array}{l}\text { Marg. } \\
\text { effect }\end{array}$ & Coeff. & $\begin{array}{l}\text { Marg. } \\
\text { effect }\end{array}$ & \\
\hline $\begin{array}{l}\text { Walking speed } \\
\text { (tests } 1 \text { and } 2 \text { ) }\end{array}$ & $\begin{array}{c}-0.142 \\
(0.76) \\
{[102]}\end{array}$ & See left & \multicolumn{2}{|c|}{$\begin{array}{l}\text { Insufficient number } \\
\text { of observations }\end{array}$} & OLS \\
\hline Maximum grip strength ${ }^{\mathrm{b}}$ & $\begin{array}{c}0.008 \\
(0.05) \\
{[6767]}\end{array}$ & See left & $\begin{array}{c}0.335 \\
(0.92) \\
{[462]}\end{array}$ & See left & OLS \\
\hline Number of usable hands & $\begin{array}{c}0.087 \\
(1.56) \\
{[6999]}\end{array}$ & $\begin{array}{l}0.005 \\
(1.35)\end{array}$ & \multicolumn{2}{|c|}{$\begin{array}{l}\text { Insufficient number } \\
\text { of observations }\end{array}$} & $\begin{array}{l}\text { Ordered } \\
\text { probit }\end{array}$ \\
\hline $\begin{array}{l}\text { Body Mass Index } \\
\text { ( } 3 \text { categories) }\end{array}$ & $\begin{array}{c}-0.000 \\
(0.00) \\
{[6987]}\end{array}$ & $\begin{array}{l}-5.71 e-06 \\
(0.00)\end{array}$ & $\begin{array}{c}0.018 \\
(0.31) \\
{[467]}\end{array}$ & $\begin{array}{c}0.007 \\
(0.31)\end{array}$ & $\begin{array}{l}\text { Ordered } \\
\text { probit }\end{array}$ \\
\hline $\begin{array}{l}\text { Orientation to date, month, } \\
\text { year, and day of the week }\end{array}$ & $\begin{array}{c}0.020 \\
(0.62) \\
{[7039]}\end{array}$ & $\begin{array}{l}0.004 \\
(0.61)\end{array}$ & $\begin{array}{c}0.031 \\
(0.20) \\
{[472]}\end{array}$ & $\begin{array}{c}0.002 \\
(0.21)\end{array}$ & $\begin{array}{l}\text { Ordered } \\
\text { probit }\end{array}$ \\
\hline Mathematical performance & $\begin{array}{l}0.052^{*} \\
(2.63) \\
{[7030]}\end{array}$ & $\begin{array}{l}0.020^{*} \\
(2.65)\end{array}$ & $\begin{array}{c}0.200^{*} \\
(3.73) \\
{[472]}\end{array}$ & $\begin{array}{l}0.079^{*} \\
(3.80)\end{array}$ & $\begin{array}{l}\text { Ordered } \\
\text { probit }\end{array}$ \\
\hline $\begin{array}{l}\text { Recalling words from a } \\
10 \text {-word list: immediate }\end{array}$ & $\begin{array}{c}0.068^{*} \\
(3.51) \\
{[6979]}\end{array}$ & $\begin{array}{l}0.005^{*} \\
(3.37)\end{array}$ & $\begin{array}{c}0.107^{\dagger} \\
(2.17) \\
{[471]}\end{array}$ & $\begin{array}{l}0.024^{\ddagger} \\
(1.87)\end{array}$ & $\begin{array}{l}\text { Ordered } \\
\text { probit }\end{array}$ \\
\hline $\begin{array}{l}\text { Recalling words from a } \\
\text { 10-word list: delayed }\end{array}$ & $\begin{array}{c}0.085^{*} \\
(4.41) \\
{[6982]}\end{array}$ & $\begin{array}{l}0.003^{*} \\
(3.87)\end{array}$ & $\begin{array}{c}0.040 \\
(0.79) \\
{[471]}\end{array}$ & $\begin{array}{c}0.009 \\
(0.76)\end{array}$ & $\begin{array}{l}\text { Ordered } \\
\text { probit }\end{array}$ \\
\hline Verbal fluency score & $\begin{array}{l}0.546^{*} \\
(4.54) \\
{[6972]}\end{array}$ & See left & $\begin{array}{c}0.439 \\
(1.81) \\
{[471]}\end{array}$ & See left & OLS \\
\hline
\end{tabular}

Notes: Ordered probit, logit, tobit, and OLS regression (SHARE). All estimations are performed with robust standard errors where technically possible. ${ }^{*},{ }^{\dagger}$, and ${ }^{\ddagger}$ indicate significance at the $1 \%, 5 \%$, and $10 \%$ levels, respectively. Absolute values of $\mathrm{t}-\mathrm{z} \mathrm{z}$-statistics are reported in round brackets and number of observations, in square brackets. Predicted outcome for a dichotomous variable is 1 and for categorical variables, the lowest or highest category that reflects the best health state. Where possible, marginal effects are calculated at the median value of the control variables of all observations retained in the regression sample.

a The same insignificant result is obtained for the time of walking tests 1 and 2 separately as dependent variables, as well as for the subjective assessment of difficulties walking 100 metres (ph048d01).

Owing to the small number of observations, the set of control variables had to be adjusted.

b A similar outcome is obtained for the first and second measurement of the right and left hands separately.

c Identical results are obtained for all questions with which this index is constructed. 
swiftly (as indicated by the verbal fluency score) and are more apt to execute mathematical tasks related to everyday situations. ${ }^{22}$ In other words, the mental abilities necessary for performing daily activities appear positively affected by job satisfaction.

The finding that job satisfaction is associated with a better subjective physical and mental health state (e.g. Tables 1 and 3) but affects intellectual abilities rather than physical health if measured objectively (Table 5) gives rise to a puzzle. More specifically, this observation speaks to the already mentioned problem of previous reliance on subjective measures of job satisfaction and health, either of which may be affected by unobserved third factors like employment conditions, past health status, or personality traits.

\subsection{Working Conditions, Previous Health Status, and Personality Traits}

The observed relation between job satisfaction and health might be spurious if driven by unobserved third factors like working conditions, previous health status, or hidden worker characteristics. First, employment conditions such as work hours, good relations with colleagues, or appropriate compensation might explain why, over time, workers develop both good health and high job satisfaction. Second, current job satisfaction might be influenced by past health problems that may also affect today's health status. Third, mood and general life perspective may equally well determine perception of one's own health and work-derived feelings of well-being. If any one were the case, job satisfaction would work as a transmission channel that proxies these other determinants but exerts no independent impact of its own. ${ }^{23}$

In the case that working conditions are affecting worker job satisfaction and health equally, job satisfaction would constitute a mediating factor that has no direct impact on health. Fortunately, the SHARE and SHP datasets provide indicators for myriad variables that allow employment conditions to be controlled for, including type of contract (short term/long term), firm sector (public/ private), workload, freedom to make decisions, career prospects, sufficiency of

22 These mathematical tasks included stating the amount of money in one's own savings account and calculating fractions, which are necessary for such activities as comparing prices or checking price changes.

23 Instead of measuring the influence of such time-invariant personality traits and job characteristics directly, an individual fixed effects estimation employing a household panel could have been carried out. Such approach is chosen in Fischer and Sousa-Poza (2008). Note that in this study a positive relation between job satisfaction and health remains. 
remuneration, job security, and working hours. ${ }^{24}$ To test for such a third factor, we include these variables into the baseline model used in Tables 1 through 5, which already takes into account the degree of managerial power, the number of supervisees, and type of job (blue collar/white collar) measured by the GOLDTHORPE classification. Being cross-sectional, the SHARE working conditions data are measured contemporaneously with health and job satisfaction; however, the SHP environmental variables (and job satisfaction) are lagged and measured as of 1999 to mitigate simultaneity bias. For comparability of results across datasets, we also narrow the analysis to those subjective health measures contained in both datasets, together with the objective measures available only in the SHARE data. The estimation results for the job satisfaction variable and the additional working condition determinants for both datasets are reported in Tables $6 \mathrm{a}, 6 \mathrm{~b}$, and 7.

As Tables $6 \mathrm{a}$ and 7 illustrate, even when working conditions are controlled for, job satisfaction still exerts a significant health-improving impact on most subjective measures of health, including health status, measures of depression, impediments to daily activities, and number of visits to physicians. ${ }^{25}$ This finding lends support to our conjecture that actual or past job satisfaction exerts a direct impact on subjective perception of health that is not mediated through actual or past work conditions. Similarly, Table 6b shows that, as in the earlier analysis, objective measures of intellectual ability (verbal fluency, word recall, mathematical performance) remain positively impacted by higher levels of job satisfaction. However, in contrast to previous results job satisfaction is now also associated with a more normal body weight (as measured by the BMI), while other objective indicators of physical health like handgrip strength and number of usable hands remain unaffected.

A comparison of the size of the marginal effects in the extended model (Tables $6 \mathrm{a}$ and $6 \mathrm{~b}$ ) with those obtained in the baseline model (Tables 1 through 5) reveals the extent to which job satisfaction functions as a transmission channel of employment conditions. The similarity of the coefficients indicates that general health assessment and intellectual ability are only somewhat affected by the inclusion or exclusion of employment condition determinants. However, on more specific health problems (back problems, impediments to daily activities, depression) the effect of job satisfaction is about twice as large in the baseline model as in the extended model, indicating that the job environment channel is at work.

24 In the SHARE data, these working condition variables are available only for employees and civil servants.

25 In the SHARE data, significance prevails in eight out of nine regression models; and in the SHP, in six out of seven cases. Exceptions pertain to sleeping problems (SHARE) and feelings of weakness (SHP). 
Table 6a: Job Satisfaction, Working Conditions, and Subjective Measures of Health - SHARE

\begin{tabular}{|c|c|c|c|c|c|c|c|c|}
\hline & 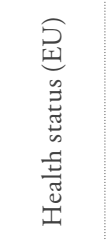 & 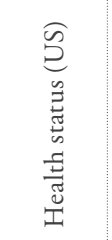 & 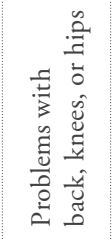 & 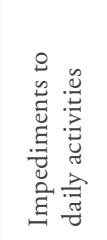 & 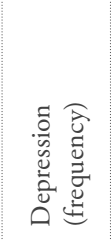 & 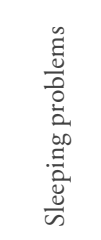 & 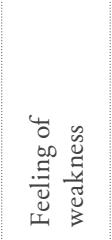 & 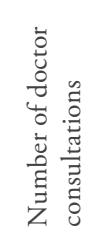 \\
\hline Baseline reported in & Table 1 & Table 1 & Table 2 & Table 2 & Table 3 & Table 3 & Table 3 & Table 4 \\
\hline Job satisfaction & $\begin{array}{c}0.178^{*} \\
(6.78)\end{array}$ & $\begin{array}{c}0.193^{*} \\
(7.69)\end{array}$ & $\begin{array}{c}-0.107^{\dagger} \\
(2.28)\end{array}$ & $\begin{array}{c}-0.123^{*} \\
(4.16)\end{array}$ & $\begin{array}{c}-0.149^{*} \\
(6.00)\end{array}$ & $\begin{array}{c}-0.191^{*} \\
(3.01)\end{array}$ & $\begin{array}{c}-0.107 \\
(0.93)\end{array}$ & $\begin{array}{l}-0.841^{*} \\
(3.02)\end{array}$ \\
\hline Marginal effect & $0.071^{*}$ & $0.071^{*}$ & $-0.026^{\dagger}$ & $-0.032^{*}$ & $-0.059^{*}$ & $-0.015^{\dagger}$ & -0.002 & \\
\hline & $0.085^{*}$ & $0.075^{*}$ & $-0.054^{*}$ & $-0.067^{*}$ & $-0.094^{*}$ & $-0.025^{*}$ & $-0.005^{\ddagger}$ & \\
\hline Time pressure & $\begin{array}{c}-0.066^{\dagger} \\
(2.05)\end{array}$ & $\begin{array}{c}-0.02 \\
(0.65)\end{array}$ & $\begin{array}{c}0.095 \\
(1.61)\end{array}$ & $\begin{array}{c}0.048 \\
(1.27)\end{array}$ & $\begin{array}{l}0.066^{\dagger} \\
(2.16)\end{array}$ & $\begin{array}{c}0.089 \\
(1.06)\end{array}$ & $\begin{array}{l}0.412^{*} \\
(2.72)\end{array}$ & $\begin{array}{c}0.532 \\
(1.48)\end{array}$ \\
\hline Physical labour & $\begin{array}{c}-0.491^{*} \\
(4.51)\end{array}$ & $\begin{array}{c}-0.485^{*} \\
(4.51)\end{array}$ & $\begin{array}{l}0.390^{\dagger} \\
(1.96)\end{array}$ & $\begin{array}{l}0.399^{*} \\
(3.04)\end{array}$ & $\begin{array}{c}0.079 \\
(0.76)\end{array}$ & $\begin{array}{c}-0.103 \\
(0.37)\end{array}$ & $\begin{array}{c}0.673 \\
(1.31)\end{array}$ & $\begin{array}{l}2.819^{\dagger} \\
(2.41)\end{array}$ \\
\hline Little freedom & $\begin{array}{c}0.043 \\
(1.16)\end{array}$ & $\begin{array}{l}-0.016 \\
(0.46)\end{array}$ & $\begin{array}{c}-0.100 \\
(1.49)\end{array}$ & $\begin{array}{c}-0.02 \\
(0.47)\end{array}$ & $\begin{array}{c}-0.012 \\
(0.33)\end{array}$ & $\begin{array}{c}-0.007 \\
(0.08)\end{array}$ & $\begin{array}{c}0.131 \\
(0.86)\end{array}$ & $\begin{array}{c}-0.277 \\
(0.69)\end{array}$ \\
\hline New skills & $\begin{array}{l}0.126^{*} \\
(3.36)\end{array}$ & $\begin{array}{l}0.096^{*} \\
(2.65)\end{array}$ & $\begin{array}{l}-0.124^{\ddagger} \\
(1.80)\end{array}$ & $\begin{array}{l}-0.094^{\dagger} \\
(2.14)\end{array}$ & $\begin{array}{c}-0.04 \\
(1.09)\end{array}$ & $\begin{array}{r}-0.155 \\
(1.63)\end{array}$ & $\begin{array}{c}-0.057 \\
(0.36)\end{array}$ & $\begin{array}{c}-0.168 \\
(0.41)\end{array}$ \\
\hline Support & $\begin{array}{c}0.055 \\
(1.43)\end{array}$ & $\begin{array}{c}0.048 \\
(1.29)\end{array}$ & $\begin{array}{l}-0.181^{\dagger} \\
(2.53)\end{array}$ & $\begin{array}{l}-0.114^{*} \\
(2.59)\end{array}$ & $\begin{array}{c}-0.184^{*} \\
(5.03)\end{array}$ & $\begin{array}{c}-0.400^{*} \\
(4.20)\end{array}$ & $\begin{array}{c}-0.019 \\
(0.11)\end{array}$ & $\begin{array}{c}-0.651 \\
(1.51)\end{array}$ \\
\hline Recognition & $\begin{array}{c}0.055 \\
(1.41)\end{array}$ & $\begin{array}{c}0.047 \\
(1.23)\end{array}$ & $\begin{array}{c}-0.047 \\
(0.64)\end{array}$ & $\begin{array}{c}-0.063 \\
(1.39)\end{array}$ & $\begin{array}{l}-0.148^{*} \\
(3.90)\end{array}$ & $\begin{array}{c}-0.035 \\
(0.36)\end{array}$ & $\begin{array}{c}-0.004 \\
(0.03)\end{array}$ & $\begin{array}{l}-0.852^{\ddagger} \\
(1.94)\end{array}$ \\
\hline Adequate salary & $\begin{array}{l}0.190^{*} \\
(5.68)\end{array}$ & $\begin{array}{l}0.084^{*} \\
(2.64)\end{array}$ & $\begin{array}{c}-0.226^{*} \\
(3.72)\end{array}$ & $\begin{array}{l}-0.122^{*} \\
(3.15)\end{array}$ & $\begin{array}{c}-0.102^{*} \\
(3.19)\end{array}$ & $\begin{array}{c}-0.122 \\
(1.41)\end{array}$ & $\begin{array}{c}-0.321^{\dagger} \\
(2.20)\end{array}$ & $\begin{array}{c}-0.408 \\
(1.10)\end{array}$ \\
\hline $\begin{array}{l}\text { Poor career } \\
\text { possibilities }\end{array}$ & $\begin{array}{c}0.011 \\
(0.34)\end{array}$ & $\begin{array}{c}-0.016 \\
(0.51)\end{array}$ & $\begin{array}{c}0.082 \\
(1.32)\end{array}$ & $\begin{array}{c}0.06 \\
(1.47)\end{array}$ & $\begin{array}{c}0.002 \\
(0.07)\end{array}$ & $\begin{array}{c}-0.016 \\
(0.18)\end{array}$ & $\begin{array}{c}-0.209 \\
(1.36)\end{array}$ & $\begin{array}{l}0.352 \\
(0.94)\end{array}$ \\
\hline No job security & $\begin{array}{c}-0.072^{\ddagger} \\
(1.90)\end{array}$ & $\begin{array}{c}-0.078^{\dagger} \\
(2.09)\end{array}$ & $\begin{array}{c}0.064 \\
(0.91)\end{array}$ & $\begin{array}{c}0.047 \\
(1.07)\end{array}$ & $\begin{array}{l}0.128^{*} \\
(3.55)\end{array}$ & $\begin{array}{c}0.234^{\dagger} \\
(2.46)\end{array}$ & $\begin{array}{c}0.293^{\ddagger} \\
(1.87)\end{array}$ & $\begin{array}{c}1.021^{\dagger} \\
(2.44)\end{array}$ \\
\hline Short-term contract & $\begin{array}{l}0.003 \\
(0.06)\end{array}$ & $\begin{array}{c}0.064 \\
(1.21)\end{array}$ & $\begin{array}{c}0.01 \\
(0.10)\end{array}$ & $\begin{array}{c}-0.006 \\
(0.09)\end{array}$ & $\begin{array}{c}-0.03 \\
(0.58)\end{array}$ & $\begin{array}{r}-0.175 \\
(1.26)\end{array}$ & $\begin{array}{l}0.206 \\
(1.03)\end{array}$ & $\begin{array}{c}-0.779 \\
(1.31)\end{array}$ \\
\hline Public sector & $\begin{array}{c}0.033 \\
(0.90)\end{array}$ & $\begin{array}{c}0.042 \\
(1.20)\end{array}$ & $\begin{array}{c}0.005 \\
(0.07)\end{array}$ & $\begin{array}{c}0.092^{\dagger} \\
(2.20)\end{array}$ & $\begin{array}{l}0.036 \\
(1.06)\end{array}$ & $\begin{array}{c}-0.007 \\
(0.08)\end{array}$ & $\begin{array}{c}0.017 \\
(0.10)\end{array}$ & $\begin{array}{c}0.138 \\
(0.34)\end{array}$ \\
\hline Baseline model & incl. & incl. & incl. & incl. & incl. & incl. & incl. & incl. \\
\hline Observations & 5538 & 5538 & 5539 & 5538 & 5502 & 5539 & 5539 & 5536 \\
\hline
\end{tabular}

Notes: see Table 3 
Table 6b: Job Satisfaction, Work Conditions, and Objective Measures of Health - SHARE

\begin{tabular}{|c|c|c|c|c|c|c|c|c|}
\hline & 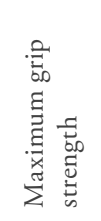 & 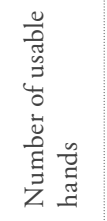 & 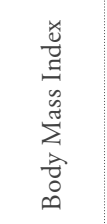 & 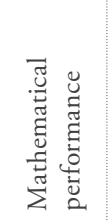 & 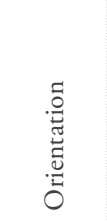 & 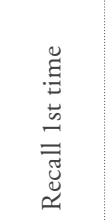 & 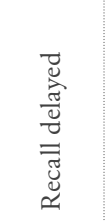 & 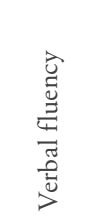 \\
\hline Baseline reported in & Table 5 & Table 5 & Table 5 & Table 5 & Table 5 & Table 5 & Table 5 & Table 5 \\
\hline Job satisfaction & $\begin{array}{c}0.090 \\
(0.49)\end{array}$ & $\begin{array}{l}0.095 \\
(1.39)\end{array}$ & $\begin{array}{l}-0.066^{\dagger} \\
(2.52)\end{array}$ & $\begin{array}{c}0.049^{\dagger} \\
(2.02)\end{array}$ & $\begin{array}{l}-0.025 \\
(0.63)\end{array}$ & $\begin{array}{c}0.046^{\ddagger} \\
(1.94)\end{array}$ & $\begin{array}{l}0.065^{*} \\
(2.70)\end{array}$ & $\begin{array}{l}0.519^{*} \\
(3.51)\end{array}$ \\
\hline Marginal effect & 0.090 & 0.001 & $-0.026^{\dagger}$ & $0.020^{\dagger}$ & -0.002 & $0.003^{\ddagger}$ & $0.003^{\dagger}$ & $0.519^{*}$ \\
\hline $\begin{array}{l}\text { Marginal effect } \\
\text { baseline model }\end{array}$ & 0.008 & 0.005 & 0.000 & $0.020^{*}$ & 0.004 & $0.005^{*}$ & $0.003^{*}$ & $0.546^{*}$ \\
\hline Time pressure & $\begin{array}{c}0.018 \\
(0.08)\end{array}$ & $\begin{array}{l}-0.351^{*} \\
(3.70)\end{array}$ & $\begin{array}{c}-0.019 \\
(0.57)\end{array}$ & $\begin{array}{l}0.123^{*} \\
(3.99)\end{array}$ & $\begin{array}{l}0.115^{\dagger} \\
(2.20)\end{array}$ & $\begin{array}{l}0.096^{*} \\
(3.29)\end{array}$ & $\begin{array}{l}0.096^{*} \\
(3.25)\end{array}$ & $\begin{array}{l}0.472^{\dagger} \\
(2.56)\end{array}$ \\
\hline Physical labour & $\begin{array}{l}-1.309^{\ddagger} \\
(1.78)\end{array}$ & $\begin{array}{l}-0.900^{\dagger} \\
(2.37)\end{array}$ & $\begin{array}{l}0.005 \\
(0.05)\end{array}$ & $\begin{array}{c}-0.274^{*} \\
(2.59)\end{array}$ & $\begin{array}{l}-0.432^{\dagger} \\
(2.23)\end{array}$ & $\begin{array}{l}0.043 \\
(0.42)\end{array}$ & $\begin{array}{c}-0.047 \\
(0.49)\end{array}$ & $\begin{array}{c}-0.862 \\
(1.27)\end{array}$ \\
\hline Little freedom & $\begin{array}{l}-0.675^{\dagger} \\
(2.57)\end{array}$ & $\begin{array}{c}0.068 \\
(0.70)\end{array}$ & $\begin{array}{c}-0.002 \\
(0.07)\end{array}$ & $\begin{array}{l}-0.007 \\
(0.19)\end{array}$ & $\begin{array}{l}-0.026 \\
(0.44)\end{array}$ & $\begin{array}{l}-0.126^{*} \\
(3.71)\end{array}$ & $\begin{array}{l}-0.074^{\dagger} \\
(2.17)\end{array}$ & $\begin{array}{l}-0.578^{*} \\
(2.59)\end{array}$ \\
\hline New skills & $\begin{array}{l}0.864^{*} \\
(3.18)\end{array}$ & $\begin{array}{c}0.049 \\
(0.52)\end{array}$ & $\begin{array}{l}0.092^{\dagger} \\
(2.37)\end{array}$ & $\begin{array}{l}0.118^{*} \\
(3.34)\end{array}$ & $\begin{array}{l}0.062 \\
(1.11)\end{array}$ & $\begin{array}{c}0.109^{*} \\
(3.17)\end{array}$ & $\begin{array}{l}0.148^{*} \\
(4.30)\end{array}$ & $\begin{array}{l}0.749^{*} \\
(3.53)\end{array}$ \\
\hline Support & $\begin{array}{l}-0.203 \\
(0.73)\end{array}$ & $\begin{array}{l}-0.088 \\
(0.76)\end{array}$ & $\begin{array}{l}0.113^{*} \\
(2.83)\end{array}$ & $\begin{array}{c}-0.012 \\
(0.32)\end{array}$ & $\begin{array}{r}0.100 \\
(1.62)\end{array}$ & $\begin{array}{l}-0.01 \\
(0.27)\end{array}$ & $\begin{array}{l}0.024 \\
(0.67)\end{array}$ & $\begin{array}{l}-0.208 \\
(0.91)\end{array}$ \\
\hline Recognition & $\begin{array}{c}-0.359 \\
(1.30)\end{array}$ & $\begin{array}{c}-0.142 \\
(1.24)\end{array}$ & $\begin{array}{l}0.036 \\
(0.88)\end{array}$ & $\begin{array}{c}-0.031 \\
(0.80)\end{array}$ & $\begin{array}{l}0.012 \\
(0.19)\end{array}$ & $\begin{array}{c}-0.013 \\
(0.34)\end{array}$ & $\begin{array}{l}-0.054 \\
(1.50)\end{array}$ & $\begin{array}{l}-0.578^{\dagger} \\
(2.54)\end{array}$ \\
\hline Adequate salary & $\begin{array}{l}0.176 \\
(0.76)\end{array}$ & $\begin{array}{c}0.112 \\
(1.21)\end{array}$ & $\begin{array}{l}0.018 \\
(0.53)\end{array}$ & $\begin{array}{l}0.124^{*} \\
(3.90)\end{array}$ & $\begin{array}{l}0.041 \\
(0.76)\end{array}$ & $\begin{array}{l}0.078^{*} \\
(2.60)\end{array}$ & $\begin{array}{l}0.101^{*} \\
(3.34)\end{array}$ & $\begin{array}{c}0.002 \\
(0.01)\end{array}$ \\
\hline $\begin{array}{l}\text { Poor career } \\
\text { possibilities }\end{array}$ & $\begin{array}{c}-0.239 \\
(1.02)\end{array}$ & $\begin{array}{l}0.189^{\dagger} \\
(2.06)\end{array}$ & $\begin{array}{c}0.037 \\
(1.05)\end{array}$ & $\begin{array}{l}0.140^{*} \\
(4.27)\end{array}$ & $\begin{array}{l}0.095^{\ddagger} \\
(1.77)\end{array}$ & $\begin{array}{l}0.063^{\dagger} \\
(2.04)\end{array}$ & $\begin{array}{l}0.077^{\dagger} \\
(2.49)\end{array}$ & $\begin{array}{l}0.638^{*} \\
(3.15)\end{array}$ \\
\hline No job security & $\begin{array}{l}-0.06 \\
(0.22)\end{array}$ & $\begin{array}{c}-0.072 \\
(0.68)\end{array}$ & $\begin{array}{c}-0.032 \\
(0.81)\end{array}$ & $\begin{array}{c}-0.076^{\dagger} \\
(2.05)\end{array}$ & $\begin{array}{c}-0.05 \\
(0.87)\end{array}$ & $\begin{array}{l}-0.006 \\
(0.17)\end{array}$ & $\begin{array}{c}-0.009 \\
(0.26)\end{array}$ & $\begin{array}{l}-0.758^{*} \\
(3.42)\end{array}$ \\
\hline $\begin{array}{l}\text { Short term } \\
\text { contract }\end{array}$ & $\begin{array}{c}0.104 \\
(0.28)\end{array}$ & $\begin{array}{l}0.064 \\
(0.40)\end{array}$ & $\begin{array}{c}0.022 \\
(0.40)\end{array}$ & $\begin{array}{c}-0.014 \\
(0.28)\end{array}$ & $\begin{array}{c}-0.101 \\
(1.33)\end{array}$ & $\begin{array}{c}-0.113^{\dagger} \\
(2.43)\end{array}$ & $\begin{array}{c}-0.064 \\
(1.30)\end{array}$ & $\begin{array}{c}0.25 \\
(0.87)\end{array}$ \\
\hline Public sector & $\begin{array}{c}-0.071 \\
(0.28)\end{array}$ & $\begin{array}{l}-0.200^{\dagger} \\
(2.02)\end{array}$ & $\begin{array}{c}-0.045 \\
(1.16)\end{array}$ & $\begin{array}{c}-0.087^{\dagger} \\
(2.47)\end{array}$ & $\begin{array}{c}-0.094 \\
(1.63)\end{array}$ & $\begin{array}{c}-0.041 \\
(1.22)\end{array}$ & $\begin{array}{c}-0.03 \\
(0.91)\end{array}$ & $\begin{array}{c}0.074 \\
(0.36)\end{array}$ \\
\hline Baseline model & incl. & incl. & incl. & incl. & incl. & incl. & incl. & incl. \\
\hline Observations & 5323 & 5508 & 5494 & 5530 & 5536 & 5489 & 5491 & 5489 \\
\hline
\end{tabular}

Notes: see Table 3 
Table 7: Past Job Satisfaction and Work Conditions - SHP Data

\begin{tabular}{|c|c|c|c|c|c|c|c|}
\hline & 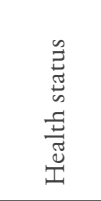 & 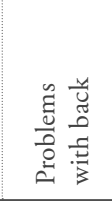 & 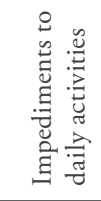 & 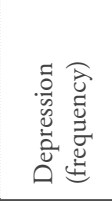 & 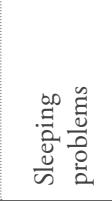 & 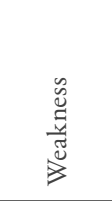 & 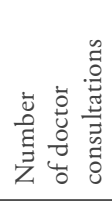 \\
\hline Job satisfaction in 1999 & $\begin{array}{l}0.065^{\dagger} \\
(2.19)\end{array}$ & $\begin{array}{l}-0.168^{*} \\
(2.70)\end{array}$ & $\begin{array}{l}-0.080^{\dagger} \\
(2.47)\end{array}$ & $\begin{array}{l}-0.124^{*} \\
(3.58)\end{array}$ & $\begin{array}{c}-0.082 \\
(1.19)\end{array}$ & $\begin{array}{l}-0.246^{*} \\
(3.92)\end{array}$ & $\begin{array}{l}-0.249^{\ddagger} \\
(1.67)\end{array}$ \\
\hline \multicolumn{8}{|l|}{ Work conditions of 1999} \\
\hline No job change & $\begin{array}{l}-0.086 \\
(0.45)\end{array}$ & $\begin{array}{l}-0.066 \\
(0.16)\end{array}$ & $\begin{array}{l}0.274 \\
(1.31)\end{array}$ & $\begin{array}{l}0.035 \\
(0.16)\end{array}$ & $\begin{array}{r}0.179 \\
(0.40)\end{array}$ & $\begin{array}{l}0.254 \\
(0.63)\end{array}$ & $\begin{array}{c}-0.891 \\
(0.95)\end{array}$ \\
\hline Public company & $\begin{array}{l}0.333^{\ddagger} \\
(1.66)\end{array}$ & $\begin{array}{l}-0.993^{\dagger} \\
(2.29)\end{array}$ & $\begin{array}{c}-0.119 \\
(0.55)\end{array}$ & $\begin{array}{c}-0.141 \\
(0.61)\end{array}$ & $\begin{array}{c}-0.491 \\
(1.01)\end{array}$ & $\begin{array}{c}-0.485 \\
(1.10)\end{array}$ & $\begin{array}{l}-0.145 \\
(0.14)\end{array}$ \\
\hline Part time & $\begin{array}{c}-0.038 \\
(0.41)\end{array}$ & $\begin{array}{c}0.131 \\
(0.67)\end{array}$ & $\begin{array}{l}0.152 \\
(1.50)\end{array}$ & $\begin{array}{l}0.339^{*} \\
(3.12)\end{array}$ & $\begin{array}{l}0.384^{\ddagger} \\
(1.76)\end{array}$ & $\begin{array}{l}0.463^{\dagger} \\
(2.32)\end{array}$ & $\begin{array}{c}0.709 \\
(1.51)\end{array}$ \\
\hline Short-term contract & $\begin{array}{c}0.382 \\
(1.26)\end{array}$ & $\begin{array}{c}-0.219 \\
(0.36)\end{array}$ & $\begin{array}{l}-0.202 \\
(0.62)\end{array}$ & $\begin{array}{c}-0.514 \\
(1.46)\end{array}$ & $\begin{array}{c}-1.031 \\
(1.42)\end{array}$ & $\begin{array}{l}-1.464^{\dagger} \\
(2.09)\end{array}$ & $\begin{array}{l}-2.446 \\
(1.62)\end{array}$ \\
\hline $\begin{array}{l}\text { No overtime } \\
\text { compensation }\end{array}$ & $\begin{array}{c}-0.023 \\
(0.17)\end{array}$ & $\begin{array}{l}0.531^{\ddagger} \\
(1.81)\end{array}$ & $\begin{array}{c}0.037 \\
(0.24)\end{array}$ & $\begin{array}{c}0.049 \\
(0.30)\end{array}$ & $\begin{array}{r}-0.075 \\
(0.22)\end{array}$ & $\begin{array}{l}0.035 \\
(0.11)\end{array}$ & $\begin{array}{l}2.548^{*} \\
(3.63)\end{array}$ \\
\hline Work at night & $\begin{array}{l}0.082 \\
(0.55)\end{array}$ & $\begin{array}{l}0.719^{\dagger} \\
(2.30)\end{array}$ & $\begin{array}{c}0.121 \\
(0.76)\end{array}$ & $\begin{array}{c}-0.18 \\
(1.03)\end{array}$ & $\begin{array}{l}-0.707^{\ddagger} \\
(1.96)\end{array}$ & $\begin{array}{l}-0.453 \\
(1.40)\end{array}$ & $\begin{array}{l}0.493 \\
(0.66)\end{array}$ \\
\hline Work in evening & $\begin{array}{l}-0.173^{\ddagger} \\
(1.72)\end{array}$ & $\begin{array}{c}-0.188 \\
(0.89)\end{array}$ & $\begin{array}{l}0.118 \\
(1.08)\end{array}$ & $\begin{array}{l}0.058 \\
(0.50)\end{array}$ & $\begin{array}{l}0.460^{\ddagger} \\
(1.96)\end{array}$ & $\begin{array}{l}0.530^{\dagger} \\
(2.46)\end{array}$ & $\begin{array}{l}0.896^{\ddagger} \\
(1.77)\end{array}$ \\
\hline Work on weekend & $\begin{array}{c}-0.106 \\
(1.09)\end{array}$ & $\begin{array}{c}0.27 \\
(1.33)\end{array}$ & $\begin{array}{c}0.037 \\
(0.35)\end{array}$ & $\begin{array}{r}0.139 \\
(1.24)\end{array}$ & $\begin{array}{l}0.384^{\ddagger} \\
(1.70)\end{array}$ & $\begin{array}{c}0.23 \\
(1.11)\end{array}$ & $\begin{array}{c}-0.406 \\
(0.83)\end{array}$ \\
\hline Fixed hours & $\begin{array}{c}-0.073 \\
(0.79)\end{array}$ & $\begin{array}{c}0.019 \\
(0.10)\end{array}$ & $\begin{array}{l}-0.057 \\
(0.58)\end{array}$ & $\begin{array}{l}0.012 \\
(0.12)\end{array}$ & $\begin{array}{c}0.259 \\
(1.20)\end{array}$ & $\begin{array}{l}0.349^{\ddagger} \\
(1.79)\end{array}$ & $\begin{array}{l}0.125 \\
(0.27)\end{array}$ \\
\hline Commuter & $\begin{array}{c}-0.005 \\
(0.05)\end{array}$ & $\begin{array}{c}-0.087 \\
(0.40)\end{array}$ & $\begin{array}{c}0.12 \\
(1.07)\end{array}$ & $\begin{array}{r}0.177 \\
(1.47)\end{array}$ & $\begin{array}{c}0.152 \\
(0.63)\end{array}$ & $\begin{array}{c}0.102 \\
(0.46)\end{array}$ & $\begin{array}{l}-0.900^{\ddagger} \\
(1.71)\end{array}$ \\
\hline No job security & $\begin{array}{l}-0.01 \\
(0.08)\end{array}$ & $\begin{array}{c}-0.108 \\
(0.40)\end{array}$ & $\begin{array}{c}0.112 \\
(0.81)\end{array}$ & $\begin{array}{c}0.23 \\
(1.55)\end{array}$ & $\begin{array}{c}0.091 \\
(0.30)\end{array}$ & $\begin{array}{c}0.367 \\
(1.36)\end{array}$ & $\begin{array}{c}0.762 \\
(1.18)\end{array}$ \\
\hline Good career prospects & $\begin{array}{c}-0.031 \\
(0.12)\end{array}$ & $\begin{array}{r}-0.561 \\
(1.05)\end{array}$ & $\begin{array}{c}0.164 \\
(0.61)\end{array}$ & $\begin{array}{c}0.148 \\
(0.51)\end{array}$ & $\begin{array}{l}-0.061 \\
(0.11)\end{array}$ & $\begin{array}{c}-0.168 \\
(0.32)\end{array}$ & $\begin{array}{c}-0.071 \\
(0.06)\end{array}$ \\
\hline $\begin{array}{l}\text { Good company } \\
\text { development }\end{array}$ & $\begin{array}{c}-0.013 \\
(0.08)\end{array}$ & $\begin{array}{l}-0.315 \\
(0.91)\end{array}$ & $\begin{array}{c}0.092 \\
(0.51)\end{array}$ & $\begin{array}{l}0.043 \\
(0.22)\end{array}$ & $\begin{array}{l}-0.669^{\ddagger} \\
(1.65)\end{array}$ & $\begin{array}{l}-0.008 \\
(0.02)\end{array}$ & $\begin{array}{l}-0.108 \\
(0.13)\end{array}$ \\
\hline High workload & $\begin{array}{l}0.034 \\
(0.36)\end{array}$ & $\begin{array}{l}0.187 \\
(0.96)\end{array}$ & $\begin{array}{l}0.035 \\
(0.34)\end{array}$ & $\begin{array}{l}-0.045 \\
(0.42)\end{array}$ & $\begin{array}{c}-0.352 \\
(1.59)\end{array}$ & $\begin{array}{c}0.101 \\
(0.51)\end{array}$ & $\begin{array}{c}0.451 \\
(0.96)\end{array}$ \\
\hline No decision & $\begin{array}{r}-0.143 \\
(1.24)\end{array}$ & $\begin{array}{c}0.222 \\
(0.93)\end{array}$ & $\begin{array}{c}0.102 \\
(0.82)\end{array}$ & $\begin{array}{l}0.240^{\ddagger} \\
(1.80)\end{array}$ & $\begin{array}{l}0.631^{\dagger} \\
(2.38)\end{array}$ & $\begin{array}{l}0.445^{\ddagger} \\
(1.81)\end{array}$ & $\begin{array}{c}-0.062 \\
(0.11)\end{array}$ \\
\hline
\end{tabular}


Table 7 (continued)

\begin{tabular}{|c|c|c|c|c|c|c|c|}
\hline & 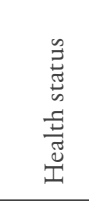 & 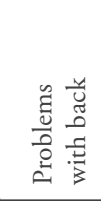 & 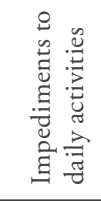 & 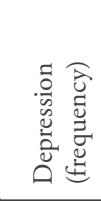 & 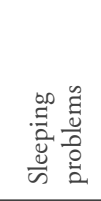 & 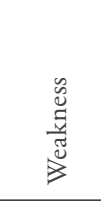 & 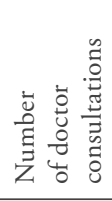 \\
\hline Satisfaction with income & $\begin{array}{c}0.101 \\
(1.12)\end{array}$ & $\begin{array}{c}-0.15 \\
(0.79)\end{array}$ & $\begin{array}{c}-0.091 \\
(0.93)\end{array}$ & $\begin{array}{c}-0.239^{\dagger} \\
(2.27)\end{array}$ & $\begin{array}{c}-0.532^{\dagger} \\
(2.50)\end{array}$ & $\begin{array}{c}-0.528^{*} \\
(2.74)\end{array}$ & $\begin{array}{c}0.044 \\
(0.10)\end{array}$ \\
\hline Risk of unemployment & $\begin{array}{c}-0.004 \\
(0.02)\end{array}$ & $\begin{array}{c}-0.039 \\
(0.09)\end{array}$ & $\begin{array}{c}0.294 \\
(1.28)\end{array}$ & $\begin{array}{c}0.497^{\dagger} \\
(2.00)\end{array}$ & $\begin{array}{l}1.367^{*} \\
(2.81)\end{array}$ & $\begin{array}{c}0.852^{\ddagger} \\
(1.89)\end{array}$ & $\begin{array}{l}3.660^{*} \\
(3.54)\end{array}$ \\
\hline Baseline model & incl. & incl. & incl. & incl. & incl. & incl. & incl. \\
\hline Observations & 2474 & 2474 & 2470 & 2474 & 2474 & 2474 & 2315 \\
\hline
\end{tabular}

Notes: see Table 3

Whereas the current state of health may well be conditioned primarily by recent health status, health problems may also restrict job choice, lead to difficulties keeping a job, and lower the life satisfaction of which job satisfaction may form a substantial part. Thus, both current health and job satisfaction may have past health as a common cause. If so, the observed impact of lagged job satisfaction on present health (see Tables 1 through 5) may be spurious; that is, job satisfaction may simply serve as a transmission channel or proxy of prior health state without exerting any direct influence of its own. To test this possibility, we make use of the SHP's panel structure by including the lagged dependent variable (i.e., the various indicators of subjective health) as an additional regressor to the extended model. As a result, we obtain an unbalanced panel of the explanatory variables "past health", "past job satisfaction", and "past working conditions" measured in 1999 and "present health outcome" from 2001 onward as dependent variable. In other words, this model regresses past job satisfaction on changes in subjective health state. ${ }^{26}$

The results in Table 8 show that in all regressions, the health indicators measured in 1999 are significant predictors of identical health measures in 2001 and beyond, at the 1 percent level. That is, even with a gap of two years or more, good health in the past is positively associated with good health in the present for all SHP health indicators. Most important, job satisfaction, however, still exerts a significant impact on a worker's present subjective health assessment in 8 out of 13 regressions. In particular, even when past health and past working conditions

26 This approach is only applicable to those cases in which the identical health measure was recorded both in 1999 and subsequently, which restricts the choice of dependent variable. 
Table 8: Past Job Satisfaction, Health, and Work Conditions - SHP data

\begin{tabular}{|c|c|c|c|c|c|c|c|}
\hline & 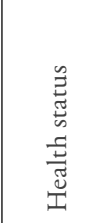 & 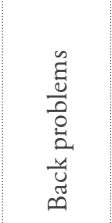 & 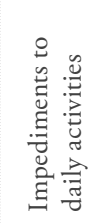 & 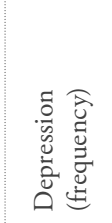 & 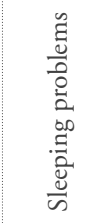 & 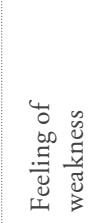 & 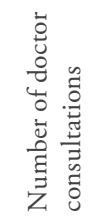 \\
\hline Job satisfaction in 1999 & $\begin{array}{l}0.046^{\ddagger} \\
(1.76)\end{array}$ & $\begin{array}{c}-0.173^{*} \\
(2.98)\end{array}$ & $\begin{array}{l}-0.037 \\
(1.27)\end{array}$ & $\begin{array}{l}-0.081^{*} \\
(2.76)\end{array}$ & $\begin{array}{c}-0.037 \\
(0.55)\end{array}$ & $\begin{array}{c}-0.198^{*} \\
(3.36)\end{array}$ & $\begin{array}{c}-0.180 \\
(1.23)\end{array}$ \\
\hline Dependent variable in 1999 & $\begin{array}{c}0.881^{*} \\
(15.46)\end{array}$ & $\begin{array}{c}3.085^{*} \\
(15.82)\end{array}$ & $\begin{array}{c}0.229^{*} \\
(12.87)\end{array}$ & $\begin{array}{c}0.361^{*} \\
(16.19)\end{array}$ & $\begin{array}{l}3.422^{*} \\
(14.56)\end{array}$ & $\begin{array}{c}2.588^{*} \\
(11.65)\end{array}$ & $\begin{array}{c}0.408^{*} \\
(14.19)\end{array}$ \\
\hline Past work conditions & incl. & incl. & incl. & incl. & incl. & incl. & incl. \\
\hline Baseline model & incl. & incl. & incl. & incl. & incl. & incl. & Incl. \\
\hline Observations & 2474 & 2471 & 2465 & 2474 & 2474 & 2468 & 2306 \\
\hline
\end{tabular}

\begin{tabular}{|c|c|c|c|c|c|c|}
\hline & 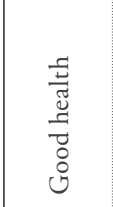 & 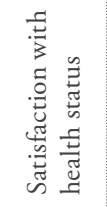 & 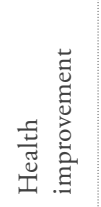 & 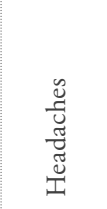 & 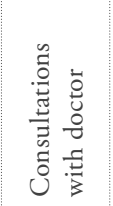 & 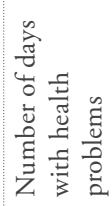 \\
\hline Job satisfaction in 1999 & $\begin{array}{l}0.110^{\ddagger} \\
(1.78)\end{array}$ & $\begin{array}{l}0.080^{*} \\
(2.92)\end{array}$ & $\begin{array}{l}0.048^{\dagger} \\
(2.17)\end{array}$ & $\begin{array}{c}-0.041 \\
(0.62)\end{array}$ & $\begin{array}{l}0.034 \\
(0.55)\end{array}$ & $\begin{array}{l}-1.432^{*} \\
(3.58)\end{array}$ \\
\hline Dependent variable in 1999 & $\begin{array}{c}2.499^{*} \\
(11.45)\end{array}$ & $\begin{array}{c}0.429^{*} \\
(18.13)\end{array}$ & $\begin{array}{l}0.080^{*} \\
(3.40)\end{array}$ & $\begin{array}{c}3.553^{*} \\
(14.84)\end{array}$ & $\begin{array}{c}2.219^{*} \\
(10.47)\end{array}$ & $\begin{array}{c}0.243^{*} \\
(12.26)\end{array}$ \\
\hline Past work conditions & incl. & incl. & incl. & incl. & incl. & incl. \\
\hline Baseline model & incl. & incl. & incl. & incl. & incl. & incl. \\
\hline Observations & 2474 & 2474 & 2473 & 2473 & 2472 & 2432 \\
\hline
\end{tabular}

Notes: see Table 3

are controlled for, the causal link between past job satisfaction and present subjective health persists for the following self-reported measures: general health status, frequency of depression or weakness, back problems, and number of days with health problems. In contrast, even though most signs of the coefficient point in the right direction, this finding breaks down for two potential symptoms of depressions - sleeping problems and headaches - and for impediments to daily activities and visits to the doctor. Given that these health problems frequently fall into the category of long-term and chronic illness, the available four-year 
maximum lag of past health may be insufficient for present health conditions likely to be determined to a greater degree by past job satisfaction rather than a history of the same disease, particularly given respondents' mature ages. In the same way, past contacts with doctors might proxy such a history of disease.

Worker characteristics like personality traits may also play some role in explaining the relation between job satisfaction and health, in particular, the traits identified by Cheng and Furnham (2001). Of these, perhaps the most relevant is negative affectivity, which has been shown to impact self-report measures of wellbeing (e.g., happiness, health worries) and even increase the number of visits to physicians (Almada, Zonderman, Shekelle, Dyer, Daviglus, Costa and Stamler, 1999; Brebner, Donaldson, Kirby and Ward, 1995; Francis, Brown, Lester and Phlilipchalk, 1998; Watson and Pennebaker, 1989). Similarly, Cramer (1991) finds a positive effect of negative affectivity on selfreported coronary heart disease, while Kohler, Scherbaum, Richter and BotTCHER (1993) and Costa (1987) fail to find a connection with objective health conditions such as blood pressure reading or coronary heart disease mortality. ${ }^{27}$ Equally, Watson and Pennebaker (1989) show that, although negative affectivity is correlated with health complaint scales, it is neither strongly nor consistently related to actual long-term health status. The latter therefore conclude that "correlations between such (subjective) measures likely overestimate the true association between stress and health" (p. 234; see also, Brief, Burke, George, Robinson and Webster, 1988; Burke, Brief and George, 1993). Thus, the causal link between job satisfaction and self-reported health in Tables 1 through 5 may also be spurious and the relationship driven rather by personality traits.

As indicators of the negative and positive affectivity identified by psychologists, Watson and Clark (1994) use a large number of adjectives that exclusively identify either mood factor. ${ }^{28}$ For example, "afraid, scared, nervous, jittery, irritable, hostile, guilty, ashamed, upset, and distressed", which can be grouped into the broader categories "fear", "hostility", "guilt", and "sadness" typify negative affectivity. Similarly, "active, alert, attentive, determined, enthusiastic, excited, inspired, interested, proud, and strong", which are classifiable into "joviality", "self-assurance", and "attentiveness", exemplify positive affectivity.

27 Nonetheless, these studies also suffer methodologically from being cross-sectional.

28 The loading factor for the trait to be measured is greater than 0.4 and that for the alternative trait is smaller than 0.125 .

29 It should be noted that sleepiness and fatigue, which are often considered proxies for depression, do not form part of the basic negative emotions but rather fall into an independent "fatigue" category of affective states. 
Other sources claim that positive affectivity leads to systematically higher levels of various types of satisfaction (e.g. life satisfaction).

Psychological questionnaires developed to test positive and negative affectivity ask subjects about the frequency of feelings corresponding to the adjectives above (the so-called PANAS/PANAS-X questionnaires). Yet, states of negative and positive affectivity do not constitute exclusive states of mind, that is, they show only a low correlation with each other (Watson, Clark and Carey, 1988). In other words, individuals may exhibit traits of both states or neither. Thus, the potentially mediating effect of job satisfaction with regards to both affective states can be tested by their simultaneous inclusion in our regression model.

Even though neither the SHARE nor the SHP survey incorporates the above descriptors of affectivivity, the mental health section of the SHARE survey does include a considerable range of loosely comparable questions. Specifically, the items on feelings of depression and expressions of guilt and self-blaming can proxy for negative affectivity, while ability to concentrate, having hopes for the future, and enjoying activities can proxy for positive affectivity. Therefore, we use these SHARE items to construct factor scores for each type of affective state (see Table 5a). ${ }^{30}$ However, given that the number of questions available in the SHARE data is by far lower than the usual 40 to 120 adjectives employed in the PANAS questionnaires, our constructed affectivity measures are most probably less reliable.

Tables $9 \mathrm{a}$ and $9 \mathrm{~b}$ present the results for the baseline model SHARE data when the factors measuring negative and positive affectivity, respectively, are included with the working condition determinants. As predicted, in all regressions of Table 9a, individuals with negative affect report significantly less satisfaction with their health status and more frequent or stronger specific health problems. In contrast, positive affective persons behave in the opposite way. Moreover, Table 9b suggests that affective state is correlated with objective measures of physical health, but equally with all intellectual abilities indicators (word recall, verbal fluency). Most important, not only does the impact of job satisfaction on subjective health variables in most regressions of Table 9a remain significant and not qualitatively change from that in the working conditions only model (Table 6a), but this

30 The variables for the factor analysis were chosen based on WATSON and CLARK (1994). Factor analysis for two factors was carried out using an iterated principal-factor method and oblique rotation that allows factors to be correlated. In the final model, the loadings for negative affectivity ranged between 0.31 and 0.71 and those for positive affectivity, between 0.25 and 0.71 . Factor scores for the two types were predicted using the Bartlett method, which produces unbiased estimates. The correlation between the two resulting factor scores is -0.1614 . 
observation holds equally for almost all objective measures of intellectual ability (Tables $9 \mathrm{~b}$ and $6 \mathrm{~b}$ ). ${ }^{31}$ Thus, contrary to expectations, job satisfaction still appears to directly influence subjective health as well as intellectual ability beyond the impact of an individual's affective state and work conditions.

Nonetheless, the marginal effects reported in Tables 6a and 6b (reprinted in the last rows of Tables $9 \mathrm{a}$ and $9 \mathrm{~b}$ ) decrease in size when personal mood factors are added to the model. Although this effect is more prominent for subjective than objective health indicators, it indicates that job satisfaction does serve as a transmission channel of affectivity - at least to some extent. Interestingly, the differences in marginal effects are largest for frequency of depression, which confirms the suggested strong connection between affective state and mental health (e.g., Watson, Clark and Carey, 1988; Lonigan, Carey and Finch, 1994). Finally, comparing the marginal effect across the three estimated models and calculating differences reveals that, for general health assessments, the contribution of working conditions to the impact of job satisfaction is roughly comparable to that of affectivity, while the first contributes more than does the latter particularly for more specific health measures (depression, back problems, daily impediments).

In contrast to the SHARE data, the SHP data allow past health status to be controlled for before health outcomes are measured but, on the other hand, provide fewer indicators of positive and negative affectivity. Again, based on WaTsON and Clark (1994), we construct factors for each affective state and add them to our model (see Table A6). ${ }^{32}$ Thus, our final model is comprised of the baseline variables (as in Tables 1 to 4), further characteristics of working conditions (as in Table 7), lagged health status (as in Table 8), and the newly included measures of negative and positive affectivity. Again, the choice of dependent health outcomes in 2001 to 2003 hinges on the availability of the identical measure in the 1999 wave.

As Table 10 shows, as expected, both positive and negative affectivity impact measures of subjective health in the expected direction (up to the 0.1 percent level

31 One exception is that, in contrast to the results in Tables $6 \mathrm{a}$ and $6 \mathrm{~b}$, inclusion of affective states leads to a loss of significance for self-reported back problems, sleep, and the ability to recall ten words immediately. As observed before, we find no relation between job satisfaction and grip strength or usability of hands.

32 We measure negative affectivity by the fear of being burglarized or attacked, feelings of anxiety, and frequency of depressions, with factor loadings ranging between 0.34 and 0.73 . Factors of positive affectivity are constructed using variables that measure satisfaction with differentiated items and interest in politics. Factor loadings range from 0.11 to 0.64 . The -0.1578 correlation between the two measures of affectivity is sufficiently low to justify their simultaneous inclusion. 
Table 9a: Negative and Positive Affectivity and Subjective Measures of Health - SHARE

\begin{tabular}{|c|c|c|c|c|c|c|c|c|}
\hline & 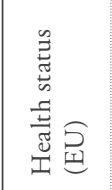 & 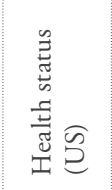 & 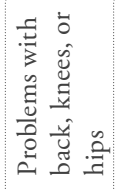 & 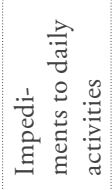 & 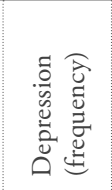 & 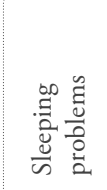 & 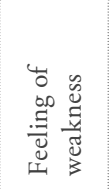 & 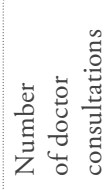 \\
\hline Job satisfaction & $\begin{array}{l}0.154^{*} \\
(5.77)\end{array}$ & $\begin{array}{l}0.169^{*} \\
(6.63)\end{array}$ & $\begin{array}{r}-0.067 \\
(1.40)\end{array}$ & $\begin{array}{l}-0.096^{*} \\
(3.22)\end{array}$ & $\begin{array}{l}-0.076^{*} \\
(2.87)\end{array}$ & $\begin{array}{r}-0.105 \\
(1.59)\end{array}$ & $\begin{array}{c}-0.043 \\
(0.39)\end{array}$ & $\begin{array}{l}-0.562^{\dagger} \\
(2.03)\end{array}$ \\
\hline Marginal effect & $0.061^{*}$ & $0.062^{*}$ & -0.016 & $-0.025^{\dagger}$ & $-0.028^{\dagger}$ & -0.008 & -0.001 & \\
\hline Negative affectivity & $\begin{array}{l}-0.174^{*} \\
(11.80)\end{array}$ & $\begin{array}{l}-0.178^{*} \\
(12.39)\end{array}$ & $\begin{array}{l}0.233^{*} \\
(8.70)\end{array}$ & $\begin{array}{c}0.185^{*} \\
(11.34)\end{array}$ & $\begin{array}{c}1.462^{*} \\
(67.28)\end{array}$ & $\begin{array}{l}0.508^{*} \\
(14.81)\end{array}$ & $\begin{array}{l}0.393^{*} \\
(7.11)\end{array}$ & $\begin{array}{c}1.543^{*} \\
(10.02)\end{array}$ \\
\hline Positive affectivity & $\begin{array}{l}0.114^{*} \\
(6.43)\end{array}$ & $\begin{array}{l}0.116^{*} \\
(6.57)\end{array}$ & $\begin{array}{l}-0.098^{*} \\
(3.14)\end{array}$ & $\begin{array}{l}-0.109^{*} \\
(5.77)\end{array}$ & $\begin{array}{l}-0.705^{*} \\
(33.93)\end{array}$ & $\begin{array}{l}-0.196^{*} \\
(5.17)\end{array}$ & $\begin{array}{c}-0.168^{*} \\
(2.85)\end{array}$ & $\begin{array}{l}-0.865^{*} \\
(4.88)\end{array}$ \\
\hline Baseline model & incl. & incl. & incl. & incl. & incl. & incl. & incl. & incl. \\
\hline Work conditions & incl. & incl. & incl. & incl. & incl. & incl. & incl. & incl. \\
\hline $\begin{array}{l}\text { Marginal effect } \\
\text { Table } 6\end{array}$ & $0.071^{*}$ & $0.071^{*}$ & $-0.026^{\dagger}$ & $-0.032^{*}$ & $-0.059^{*}$ & $-0.015^{\dagger}$ & -0.002 & \\
\hline Observations & 5494 & 5494 & 5495 & 5494 & 5491 & 5495 & 5495 & 5492 \\
\hline
\end{tabular}

Table 9b: Negative and Positive Affectivity and Objective Measures of Health - SHARE

\begin{tabular}{|c|c|c|c|c|c|c|c|c|}
\hline & & & & & & & & \\
\hline & 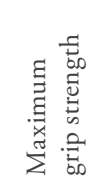 & 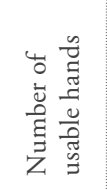 & 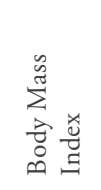 & 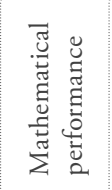 & 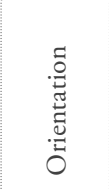 & 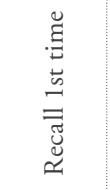 & 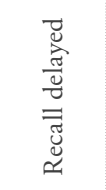 & 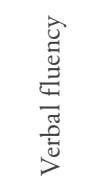 \\
\hline Job satisfaction & $\begin{array}{l}0.030 \\
(0.16)\end{array}$ & $\begin{array}{l}0.077 \\
(1.13)\end{array}$ & $\begin{array}{c}-0.074^{*} \\
(2.82)\end{array}$ & $\begin{array}{l}0.043^{\ddagger} \\
(1.76)\end{array}$ & $\begin{array}{c}-0.020 \\
(0.50)\end{array}$ & $\begin{array}{c}0.039 \\
(1.61)\end{array}$ & $\begin{array}{c}0.058^{\dagger} \\
(2.40)\end{array}$ & $\begin{array}{l}0.507^{*} \\
(3.41)\end{array}$ \\
\hline Marginal effect & 0.077 & 0.001 & $-0.029^{\dagger}$ & $0.017^{\ddagger}$ & -0.001 & 0.003 & $0.003^{\dagger}$ & $0.507^{*}$ \\
\hline Negative affectivity & $\begin{array}{l}-0.286^{*} \\
(2.90)\end{array}$ & $\begin{array}{l}-0.04 \\
(1.12)\end{array}$ & $\begin{array}{l}-0.038^{\dagger} \\
(2.48)\end{array}$ & $\begin{array}{l}-0.044^{*} \\
(3.20)\end{array}$ & $\begin{array}{l}-0.049^{\dagger} \\
(2.23)\end{array}$ & $\begin{array}{c}0.022 \\
(1.60)\end{array}$ & $\begin{array}{c}-0.004 \\
(0.29)\end{array}$ & $\begin{array}{l}0.249^{*} \\
(3.02)\end{array}$ \\
\hline \multirow[t]{2}{*}{ Positive affectivity } & \multirow{2}{*}{$\begin{array}{c}0.163 \\
(1.30)\end{array}$} & \multirow{2}{*}{$\begin{array}{l}0.100^{*} \\
(2.86)\end{array}$} & \multirow{2}{*}{$\begin{array}{c}0.003 \\
(0.16)\end{array}$} & \multirow{2}{*}{$\begin{array}{l}0.095^{*} \\
(5.87)\end{array}$} & \multirow{2}{*}{$\begin{array}{c}0.039 \\
(1.56)\end{array}$} & \multirow{2}{*}{$\begin{array}{l}0.118^{*} \\
(7.86)\end{array}$} & \multirow{2}{*}{$\begin{array}{l}0.111^{*} \\
(6.77)\end{array}$} & $0.678^{*}$ \\
\hline & & & & & & & & $(7.17)$ \\
\hline Baseline model & incl. & incl. & incl. & incl. & incl. & incl. & incl. & incl. \\
\hline Work conditions & incl. & incl. & incl. & incl. & incl. & incl. & incl. & incl. \\
\hline $\begin{array}{l}\text { Marginal effect } \\
\text { Table } 6\end{array}$ & 0.090 & 0.001 & $-0.026^{\dagger}$ & $0.020^{\dagger}$ & -0.002 & $0.003^{\ddagger}$ & $0.003^{\dagger}$ & $0.519^{*}$ \\
\hline Observations & 5302 & 5478 & 5450 & 5486 & 5492 & 5465 & 5466 & 5467 \\
\hline
\end{tabular}

Notes: see Table 3 
Table 10: Negative and Positive Affectivity - SHP

\begin{tabular}{|c|c|c|c|c|c|c|c|}
\hline & 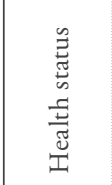 & 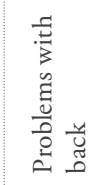 & 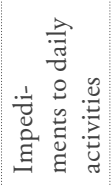 & 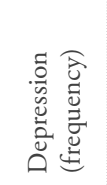 & 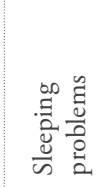 & 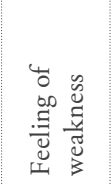 & 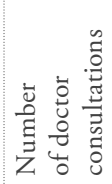 \\
\hline Job satisfaction & $\begin{array}{l}0.008 \\
(0.29)\end{array}$ & $\begin{array}{l}-0.175^{*} \\
(2.87)\end{array}$ & $\begin{array}{l}0.006 \\
(0.19)\end{array}$ & $\begin{array}{l}-0.049^{\ddagger} \\
(1.66)\end{array}$ & $\begin{array}{c}0.012 \\
(0.17)\end{array}$ & $\begin{array}{l}-0.104^{\ddagger} \\
(1.68)\end{array}$ & $\begin{array}{c}-0.003 \\
(0.02)\end{array}$ \\
\hline Dependent Variable in 1999 & $\begin{array}{l}0.816^{*} \\
(14.05)\end{array}$ & $\begin{array}{l}3.091^{*} \\
(15.56)\end{array}$ & $\begin{array}{c}0.218^{*} \\
(12.17)\end{array}$ & $\begin{array}{l}0.318^{*} \\
(12.79)\end{array}$ & $\begin{array}{l}3.418^{*} \\
(14.23)\end{array}$ & $\begin{array}{l}2.285^{*} \\
(10.08)\end{array}$ & $\begin{array}{l}0.395^{*} \\
(13.41)\end{array}$ \\
\hline Negative affectivity & $\begin{array}{l}-0.082^{\dagger} \\
(2.57)\end{array}$ & $\begin{array}{l}0.217^{*} \\
(2.97)\end{array}$ & $\begin{array}{l}0.078^{\dagger} \\
(2.25)\end{array}$ & $\begin{array}{l}0.086^{\dagger} \\
(2.19)\end{array}$ & $\begin{array}{l}0.167^{\dagger} \\
(2.00)\end{array}$ & $\begin{array}{l}0.230^{*} \\
(3.22)\end{array}$ & $\begin{array}{l}0.463^{\dagger} \\
(2.56)\end{array}$ \\
\hline Positive affectivity & $\begin{array}{l}0.143^{*} \\
(4.40)\end{array}$ & $\begin{array}{c}0.040 \\
(0.55)\end{array}$ & $\begin{array}{c}-0.141^{*} \\
(4.00)\end{array}$ & $\begin{array}{l}-0.141^{*} \\
(3.90)\end{array}$ & $\begin{array}{l}-0.205^{\dagger} \\
(2.40)\end{array}$ & $\begin{array}{l}-0.393^{*} \\
(5.27)\end{array}$ & $\begin{array}{l}-0.695^{*} \\
(3.80)\end{array}$ \\
\hline Baseline model & incl. & incl. & incl. & incl. & incl. & incl. & incl. \\
\hline Past conditions of work & incl. & incl. & incl. & incl. & incl. & incl. & incl. \\
\hline $\begin{array}{l}\text { Significance level of job } \\
\text { satisfaction variable in Table } 8\end{array}$ & $\ddagger$ & * & - & * & - & * & - \\
\hline Observations & 2409 & 2406 & 2400 & 2409 & 2409 & 2403 & 2242 \\
\hline
\end{tabular}

\begin{tabular}{|c|c|c|c|c|c|c|}
\hline & \multirow[b]{2}{*}{ 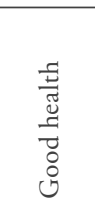 } & \multirow[b]{2}{*}{ 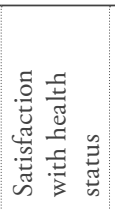 } & \multirow[b]{2}{*}{ 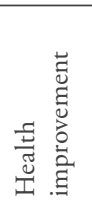 } & \multirow[b]{2}{*}{ 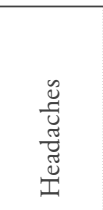 } & \multirow[b]{2}{*}{ 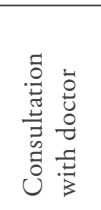 } & \multirow[b]{2}{*}{ 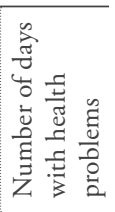 } \\
\hline & & & & & & \\
\hline Job satisfaction & $\begin{array}{l}0.028 \\
(0.43)\end{array}$ & $\begin{array}{c}0.04 \\
(1.40)\end{array}$ & $\begin{array}{l}0.034 \\
(1.49)\end{array}$ & $\begin{array}{c}0.041 \\
(0.58)\end{array}$ & $\begin{array}{l}0.096 \\
(1.54)\end{array}$ & $\begin{array}{l}-1.080^{*} \\
(2.58)\end{array}$ \\
\hline Dependent Variable in 1999 & $\begin{array}{c}2.292^{*} \\
(10.36)\end{array}$ & $\begin{array}{c}0.401^{*} \\
(16.21)\end{array}$ & $\begin{array}{l}0.072^{*} \\
(2.99)\end{array}$ & $\begin{array}{l}3.528^{*} \\
(14.49)\end{array}$ & $\begin{array}{l}2.231^{*} \\
(10.71)\end{array}$ & $\begin{array}{l}0.238^{*} \\
(11.95)\end{array}$ \\
\hline Negative affectivity & $\begin{array}{c}-0.168^{\dagger} \\
(2.26)\end{array}$ & $\begin{array}{c}-0.012 \\
(0.37)\end{array}$ & $\begin{array}{l}-0.04 \\
(1.46)\end{array}$ & $\begin{array}{l}0.212^{*} \\
(2.64)\end{array}$ & $\begin{array}{c}0.052 \\
(0.67)\end{array}$ & $\begin{array}{c}-0.241 \\
(0.48)\end{array}$ \\
\hline Positive affectivity & $\begin{array}{l}0.358^{*} \\
(4.70)\end{array}$ & $\begin{array}{l}0.185^{*} \\
(5.35)\end{array}$ & $\begin{array}{l}0.057^{\dagger} \\
(2.08)\end{array}$ & $\begin{array}{l}-0.270^{*} \\
(3.27)\end{array}$ & $\begin{array}{c}-0.185^{\dagger} \\
(2.35)\end{array}$ & $\begin{array}{l}-1.766^{*} \\
(3.53)\end{array}$ \\
\hline Baseline model & incl. & incl. & incl. & incl. & incl. & incl. \\
\hline Past conditions of work & incl. & incl. & incl. & incl. & incl. & incl. \\
\hline $\begin{array}{l}\text { Significance level of job } \\
\text { satisfaction variable in Table } 8\end{array}$ & $\ddagger$ & * & $\dagger$ & - & - & * \\
\hline Observations & 2409 & 2409 & 2408 & 2408 & 2407 & 2368 \\
\hline
\end{tabular}


of significance). However, compared to previous results (replicated in Table 10, last row) the inclusion of affectivity measures causes the job satisfaction coefficient to lose its significance completely, particularly for the self-reported measures of general health (satisfaction with health status, being in good health, health improvement ), and lowers statistical significance for the two depression measures "frequency of depression" and "feelings of weakness" from a strong 1 percent level in Table 8 down to a rather wobbly 10 percent level.

Nonetheless, inclusion of affective measures does not alter the causal link between job satisfaction and back problems, number of days with health problems (at the 5 percent level), or frequency and symptoms of depressions (albeit weak). As argued before, it may well be that these illnesses are rather long term and therefore not fully caused by the mental state or job satisfaction measured two to four years previously.

Overall, these findings suggest that the influence of affectivity is fully mediated through job satisfaction for general health perception, but only partly so for the assessment of more specific isolated, potentially persistent health problems. Thus, on the one hand, the more specific the health questions asked, the smaller the mediating effect of job satisfaction, which would make job satisfaction an important determinant in its own right. On the other hand, the scarcity of the SHP data with respect to number of available waves, objective measures of health, and indicators of moods prevents a final generalization of our estimation results.

\section{Conclusion}

This paper analyzes the impact of job satisfaction on the health of persons 50 or older using a national Swiss panel dataset and an international cross-section. The initial analysis in search of a link between health status and job satisfaction is based on subjective measures; the second, on objective measures.

Using data from the Swiss Household Panel, we show that self-reported measures of health in the years 2001 to 2003 are positively influenced by the job satisfaction reported in 1999. Lagging job satisfaction reveals an unambiguously increasing effect of job satisfaction on subjective health; that is, any bias due to endogeneity is at least mitigated. The close correspondence of our findings with those of previous cross-sectional studies or panel studies that apply an individual fixed effects technique indicates that the (likelihood of an) endogeneity bias in cross-sectional studies of workers aged 50 or older is minimal (FISCHER and Sousa-Poza, 2008; Faragher, Cass and Cooper, 2005). We also identify 
a similar link between subjective health and job satisfaction using an international cross-section. With respect to more specific health problems, job satisfaction appears to decrease the number of self-reported impediments to daily activities and self-reported frequency of depression as measured by various symptoms. Equally, job satisfaction does appear to decrease the occurrence of recalled medical treatment as measured by the self-report number of doctor visits or hospital stays, or the length of time in hospital.

Based on the objective measures in the SHARE dataset for physical health and mental abilities, we find no statistically significant link between job satisfaction and performances in tests of physical health. Moreover, with respect to intellectual abilities, individuals who are more satisfied with their jobs are also intellectually more capable, particularly in mathematics, precise recall of words, and verbal fluency.

Thus, not only do our results for subjective measures of health imply a causal relationship between self-reported measures of employee health and job satisfaction, but a robustness test reveals that this effect of job satisfaction goes beyond the influence of working conditions and therefore does not fully mediate them. Moreover, for self-reported general health assessment and symptoms of depression, we show that the health-improving impact of job satisfaction pertains not only to levels of health but also to changes in health. In contrast, results for the SHP data show that chronic and long-lasting diseases are more likely to be determined by past health status than by past job satisfaction.

Admittedly, even though knowing what affects self-reported health is important (Burke, Brief and George, 1993), this relation may be partly driven by personal traits like negative affectivity. If so, this problem would probably be best tackled by using objective measures of health or taking mood factors directly into account. Indeed, in the SHARE dataset, when affectivity is controlled for, our results indicate almost no correlation between job satisfaction and directly observable physical health. However, job satisfaction remains strongly linked to intellectual abilities. Unfortunately, the SHARE dataset, being cross-sectional, does not allow automatic inference of a causal relationship. However, in the comprehensive model estimated with SHP panel data, the link between past job satisfaction and current subjective general health assessment breaks down with the inclusion of positive and negative affectivity. Nonetheless, in both SHARE and SHP samples, for self-reported measures of more specific health problems and some symptoms of depressions, a causal relation with job satisfaction is evident that goes beyond working conditions, prior health state, and even affectivity.

In general, any causal relation between job satisfaction and worker health can be expected to diminish as the time gap between it and the objective health 
state measurement increases. Thus, the nature of this relation may be revealed by exploiting the panel structure when future waves of the SHARE survey become available. A continuously weaker relation between lagged job satisfaction and measures of health would support a causal relation between the two, while a time-invariant, equally strong linkage would call for an alternative explanation such as the negative affectivity hypothesis.

Until the issue of causality is resolved, policy recommendations can only be preliminary. Nonetheless, for the cross-section analysis, our finding that through the job satisfaction channel working conditions contribute to general worker health almost as much as affectivity, goes against common assumption. Clearly, improvements in working conditions would be conducive to improving the health perception whose impact on worker well-being and productivity is already widely discussed. However, our panel data results suggest that it is past health and mood factors that make workers perceive themselves to be in ill health. In light of such results, a good health policy would ideally begin during childhood and the teen years to actively fight a bad health spiral; for example, by promoting sufficient physical exercise and healthy nutrition. In addition, the causes of negative affectivity should be addressed during childhood, while positive affectivity traits should be supported as they develop. Such preemptive measures taken today will most probably help future health care cost reduction. 


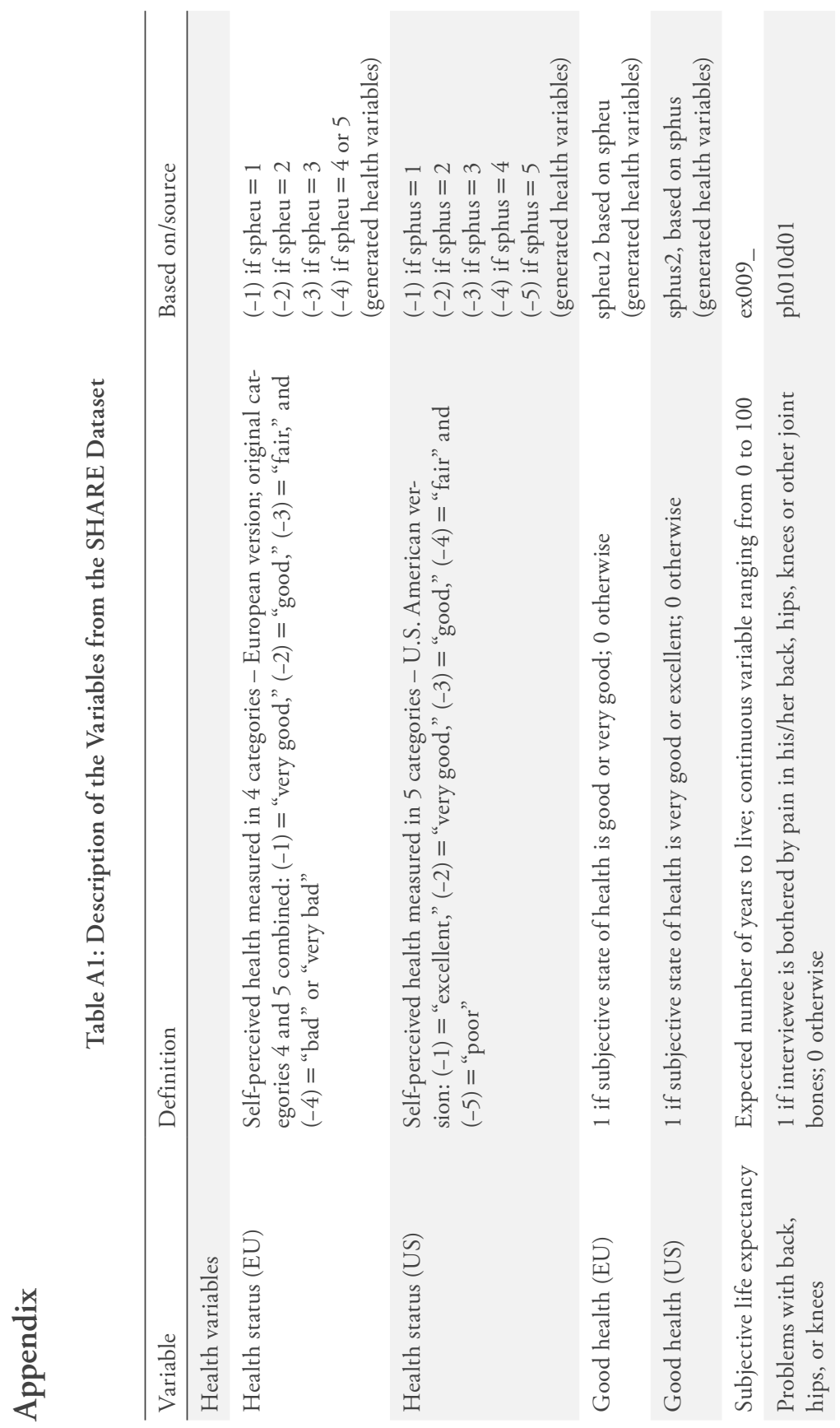




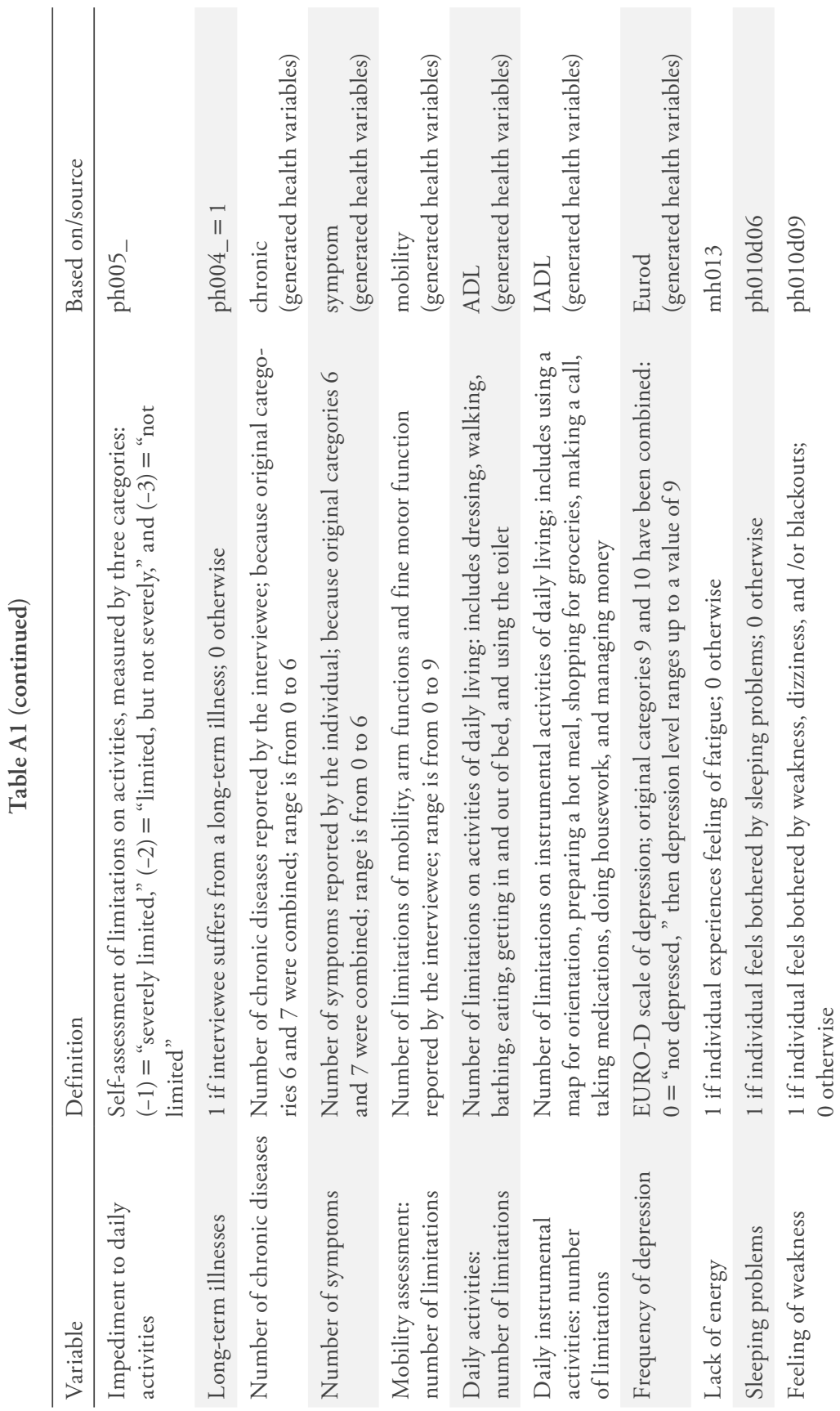




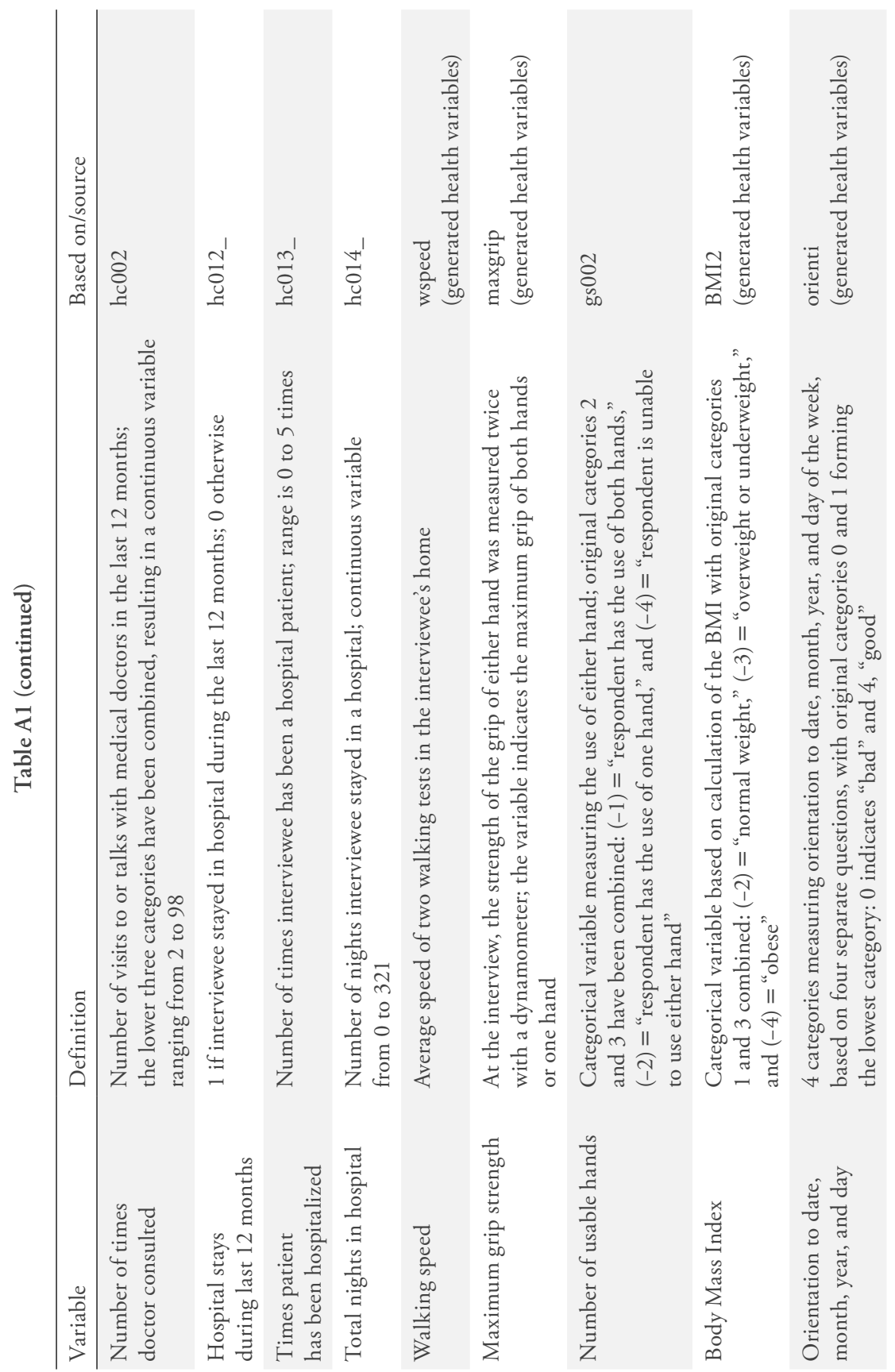




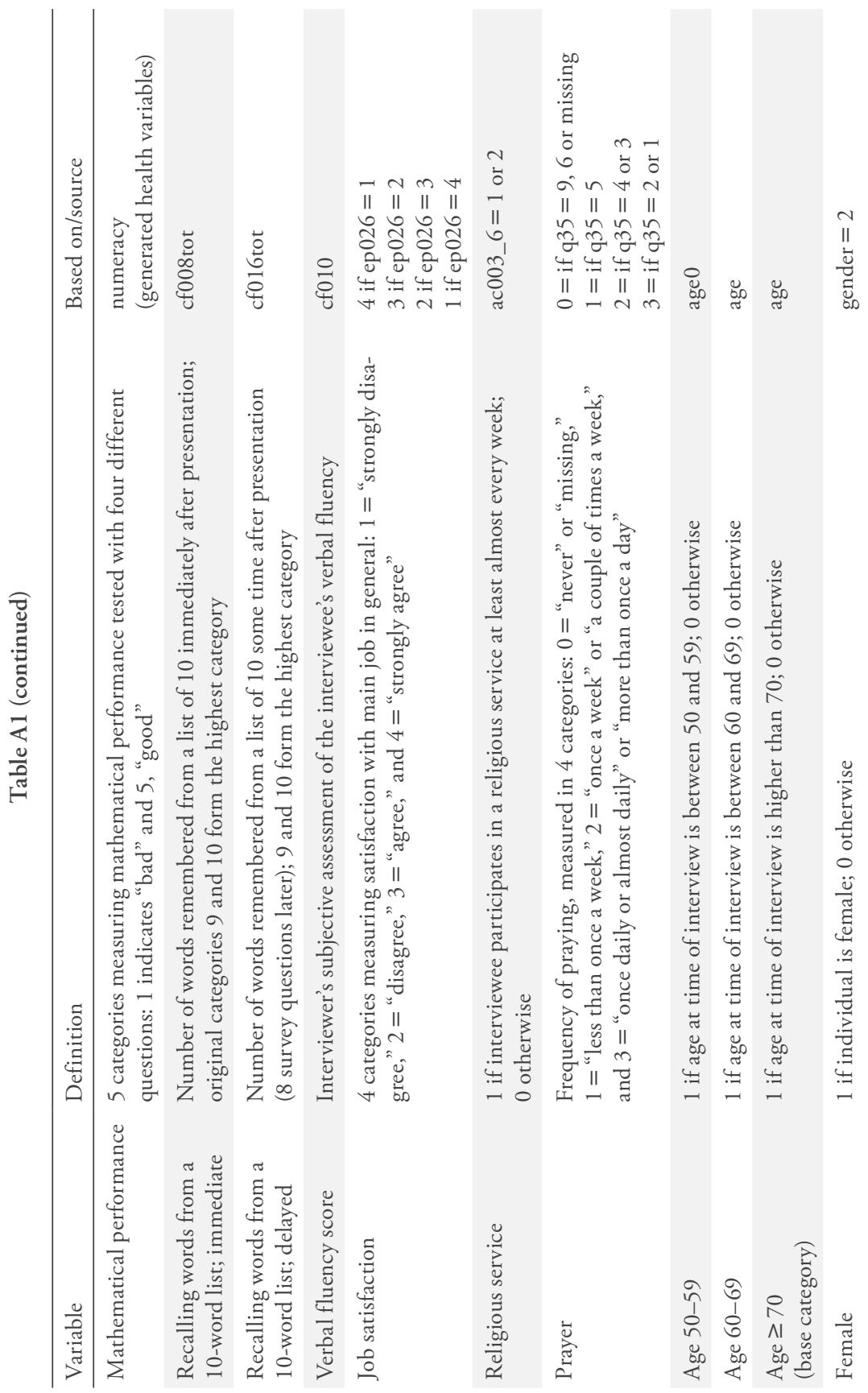




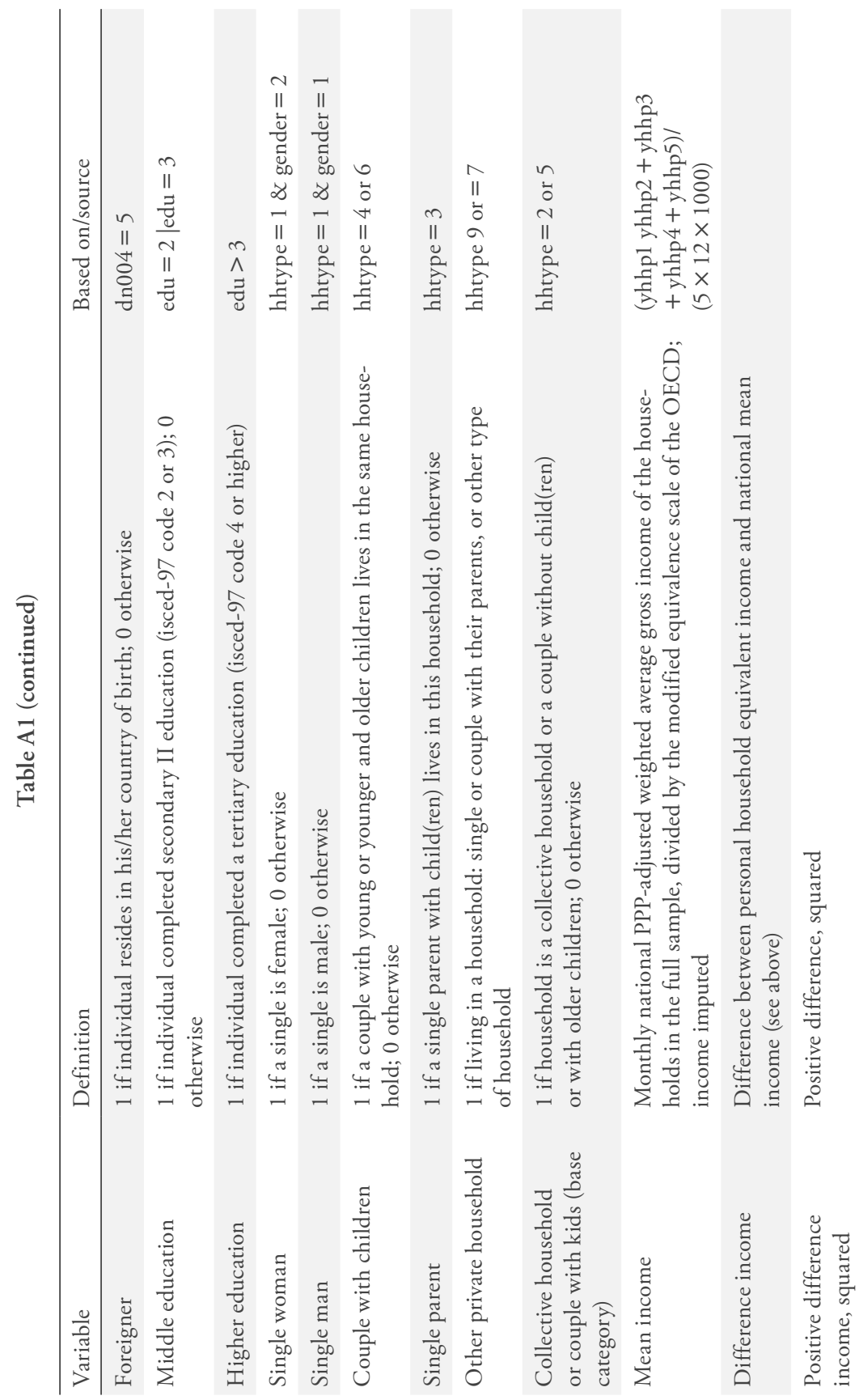




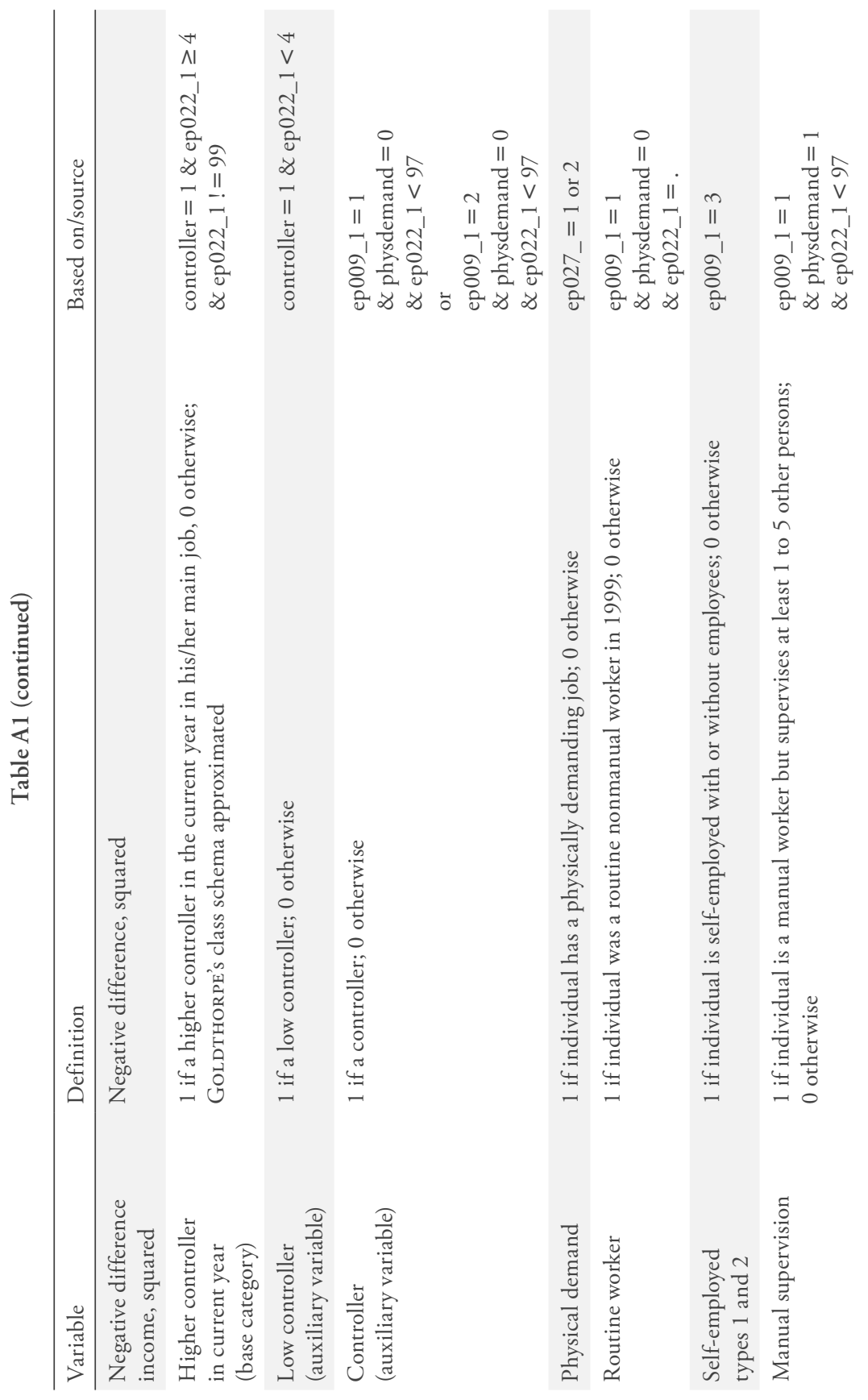




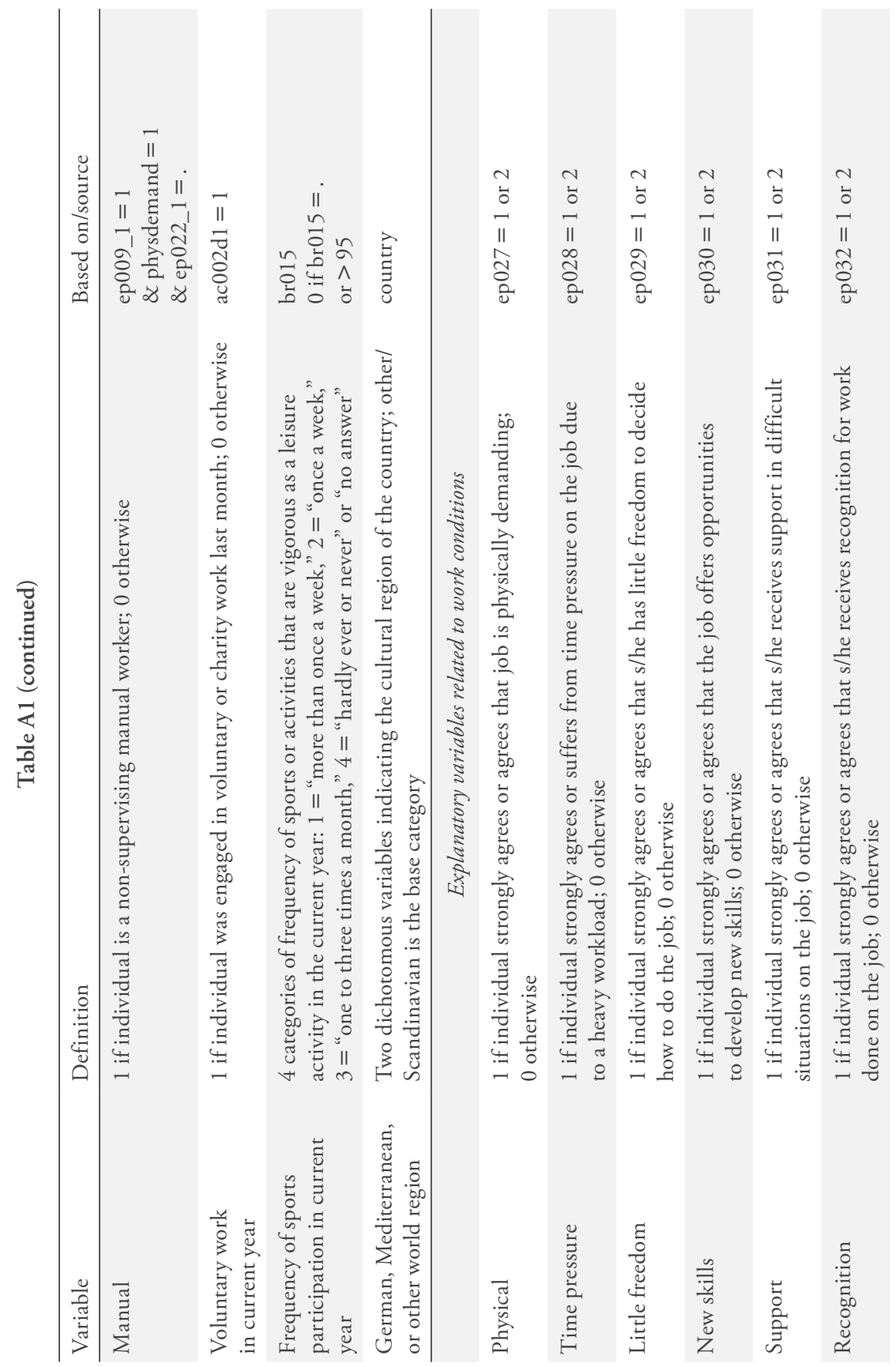



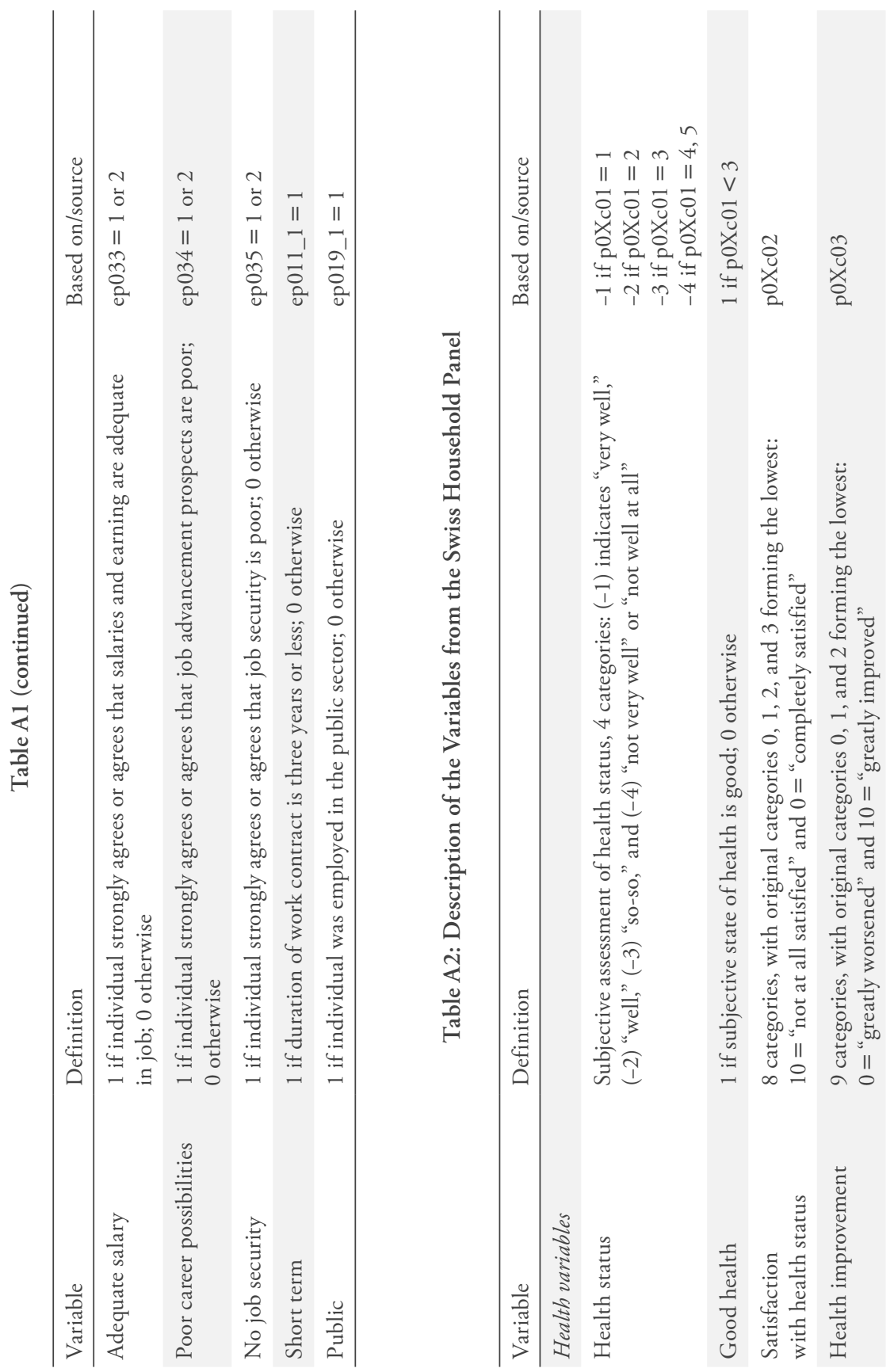


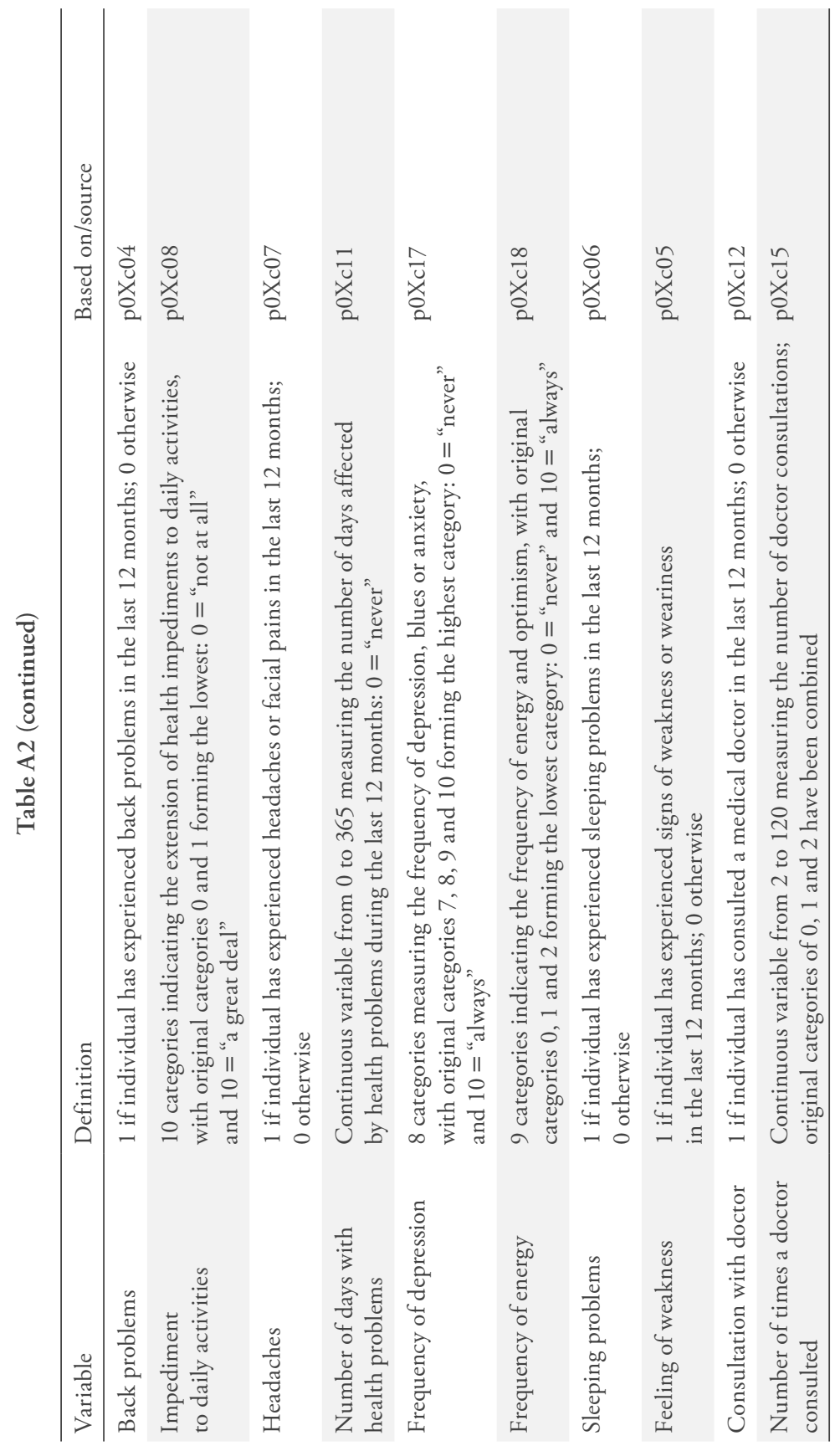




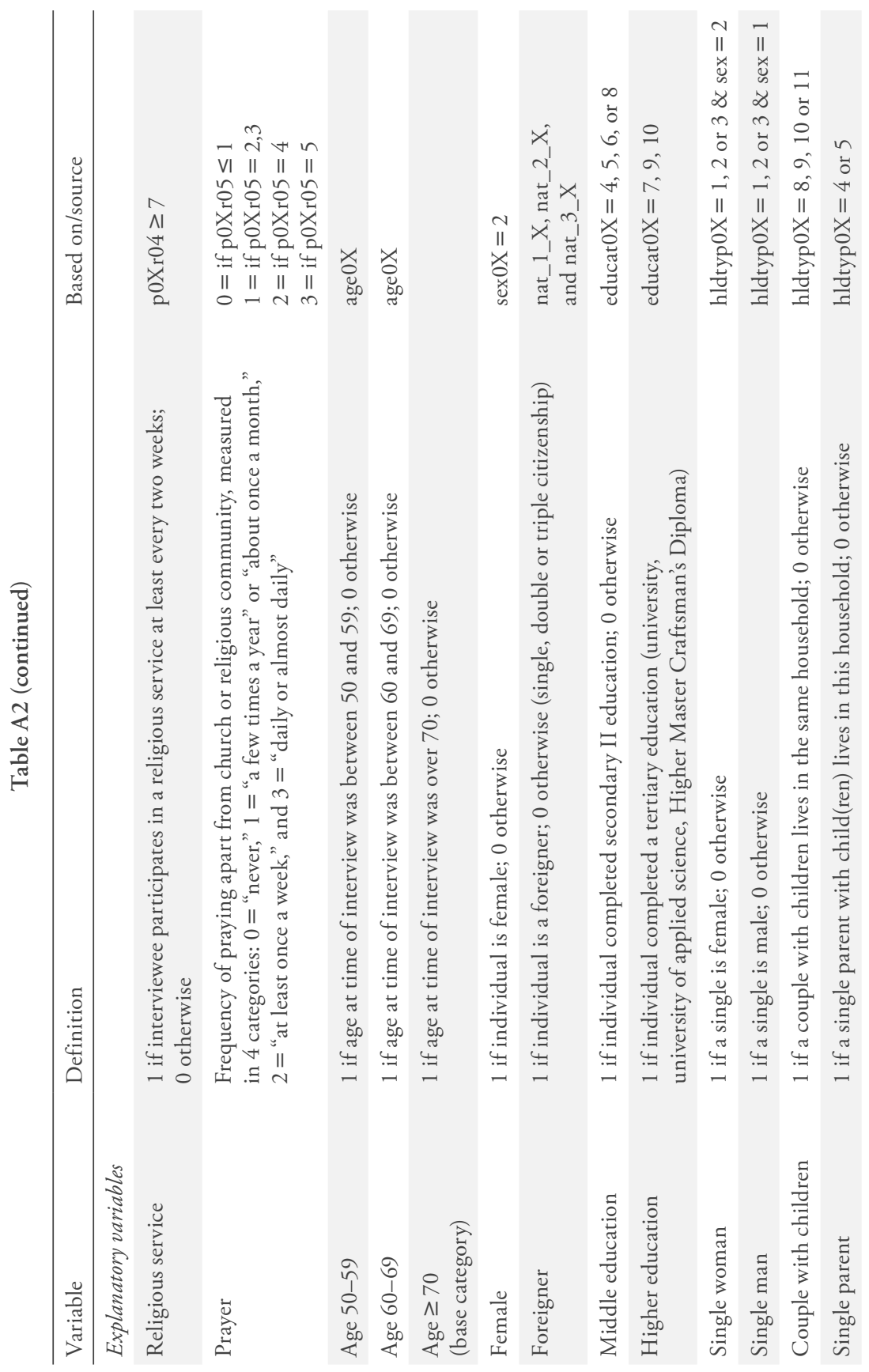




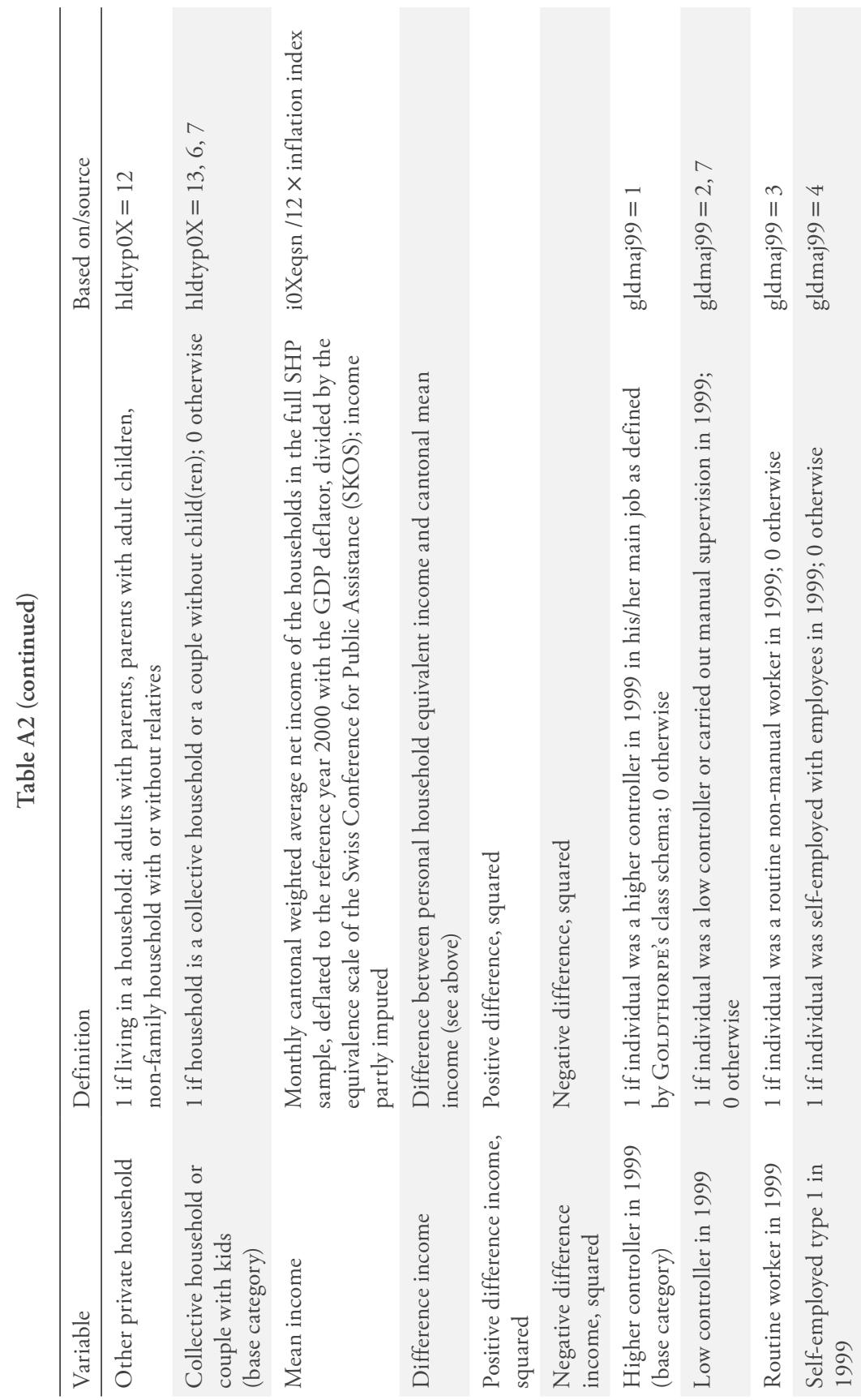




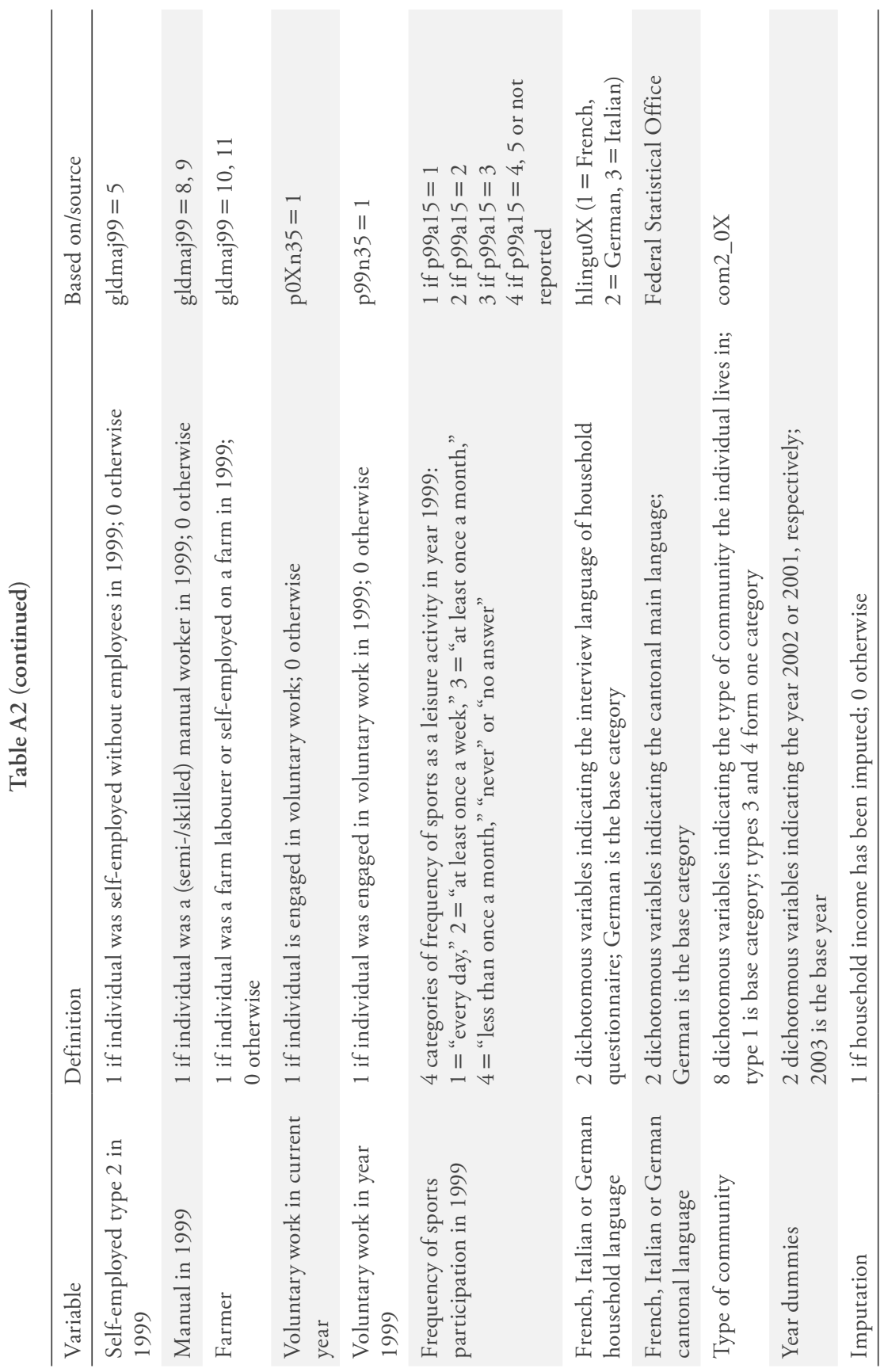




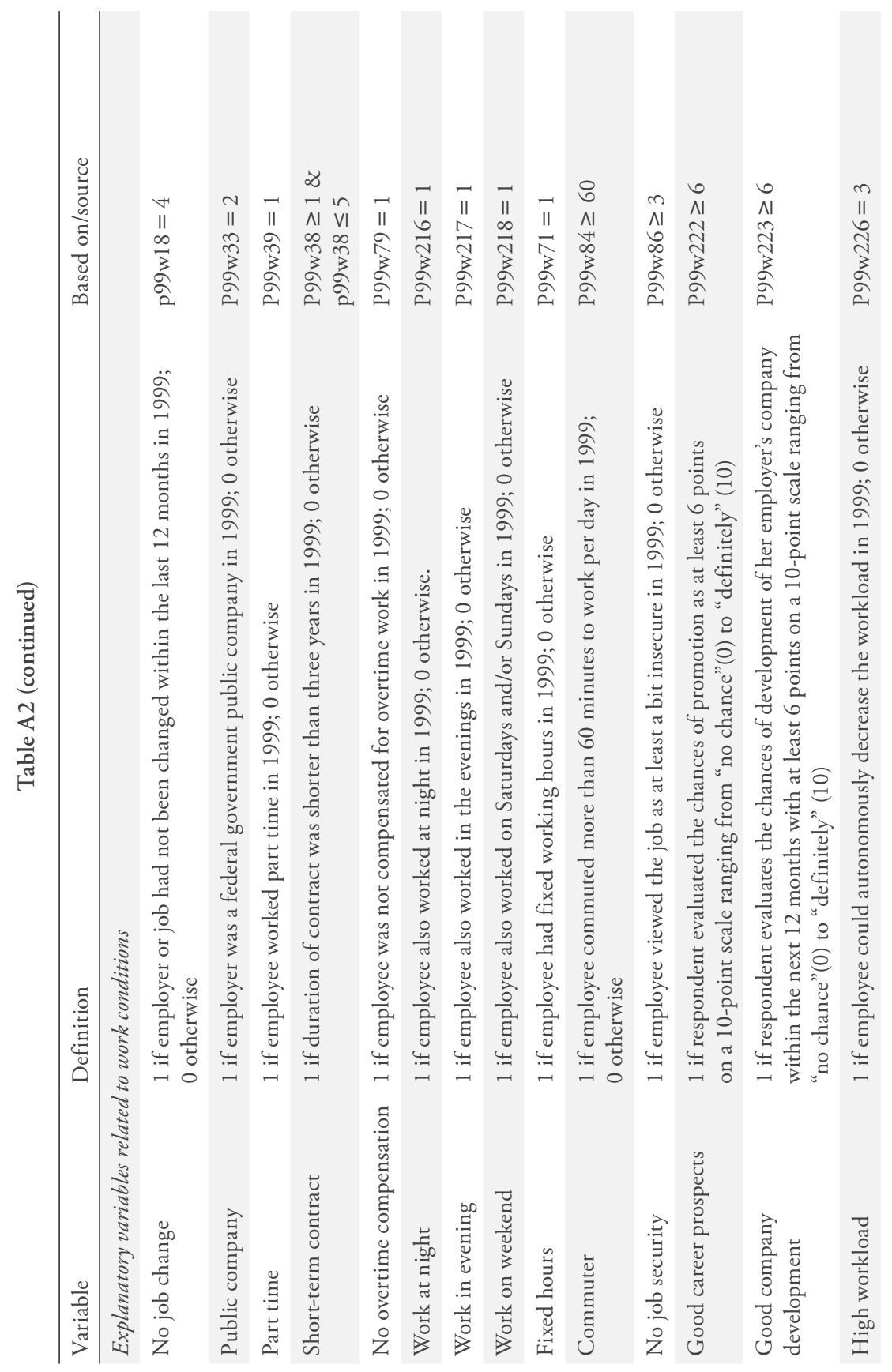



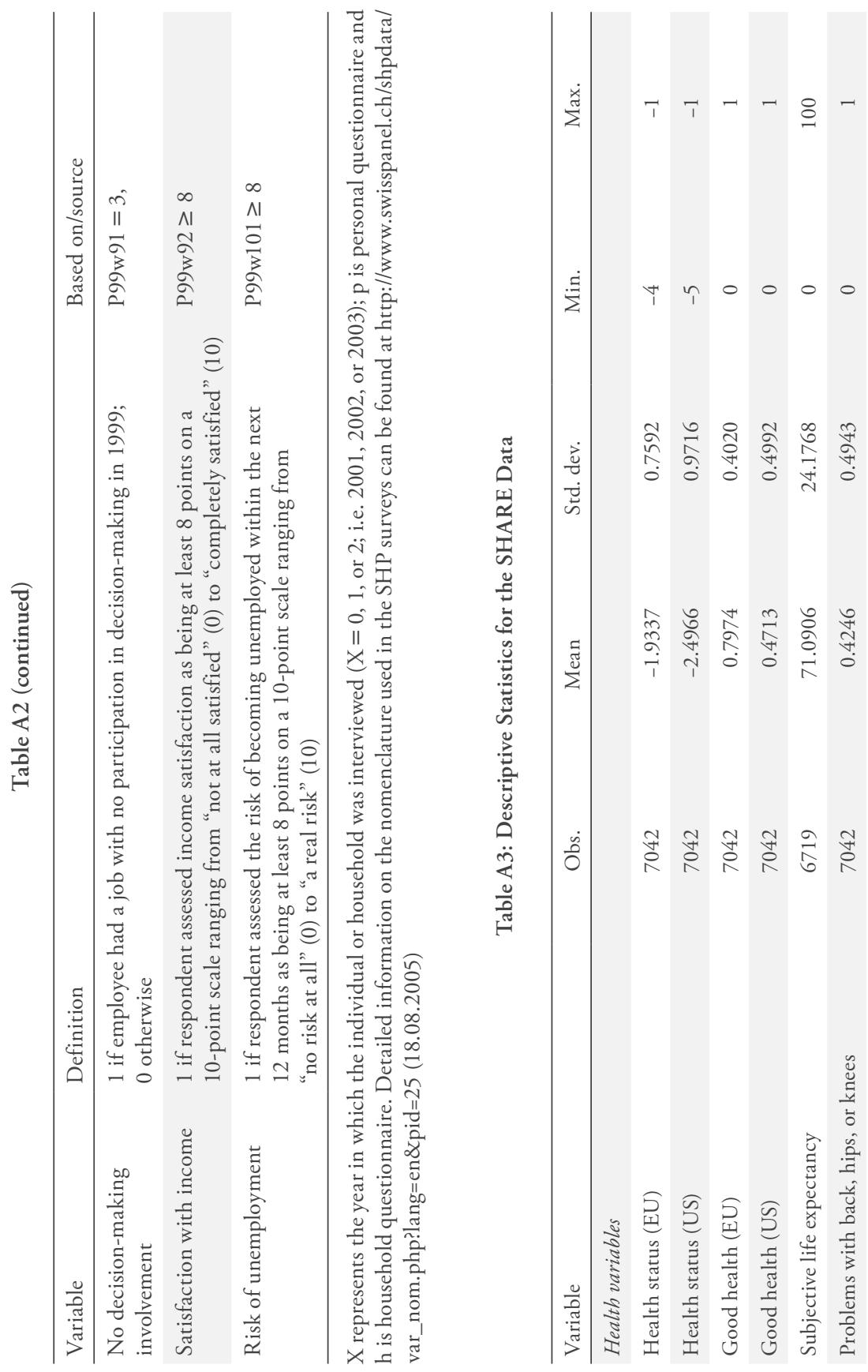


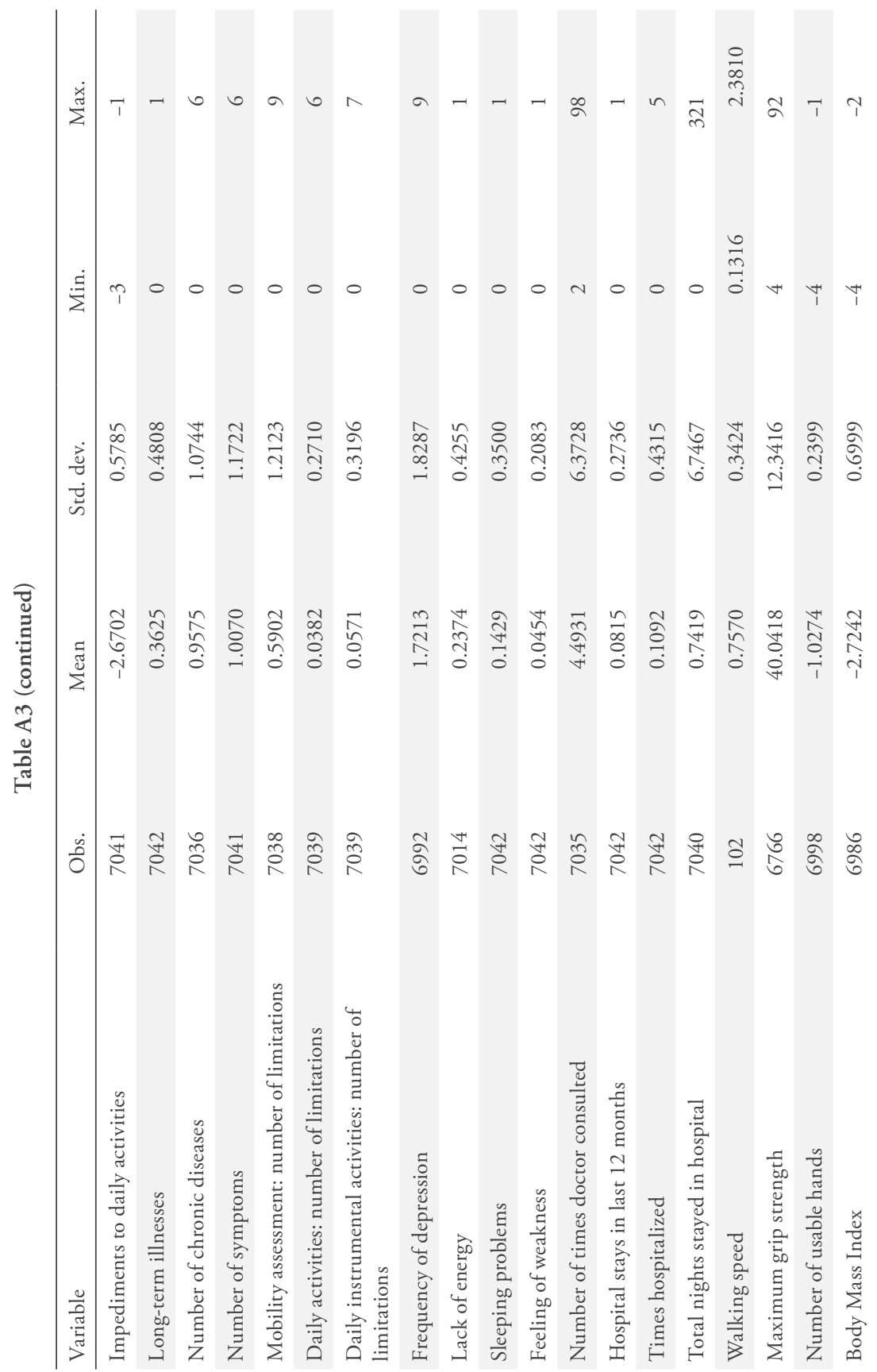




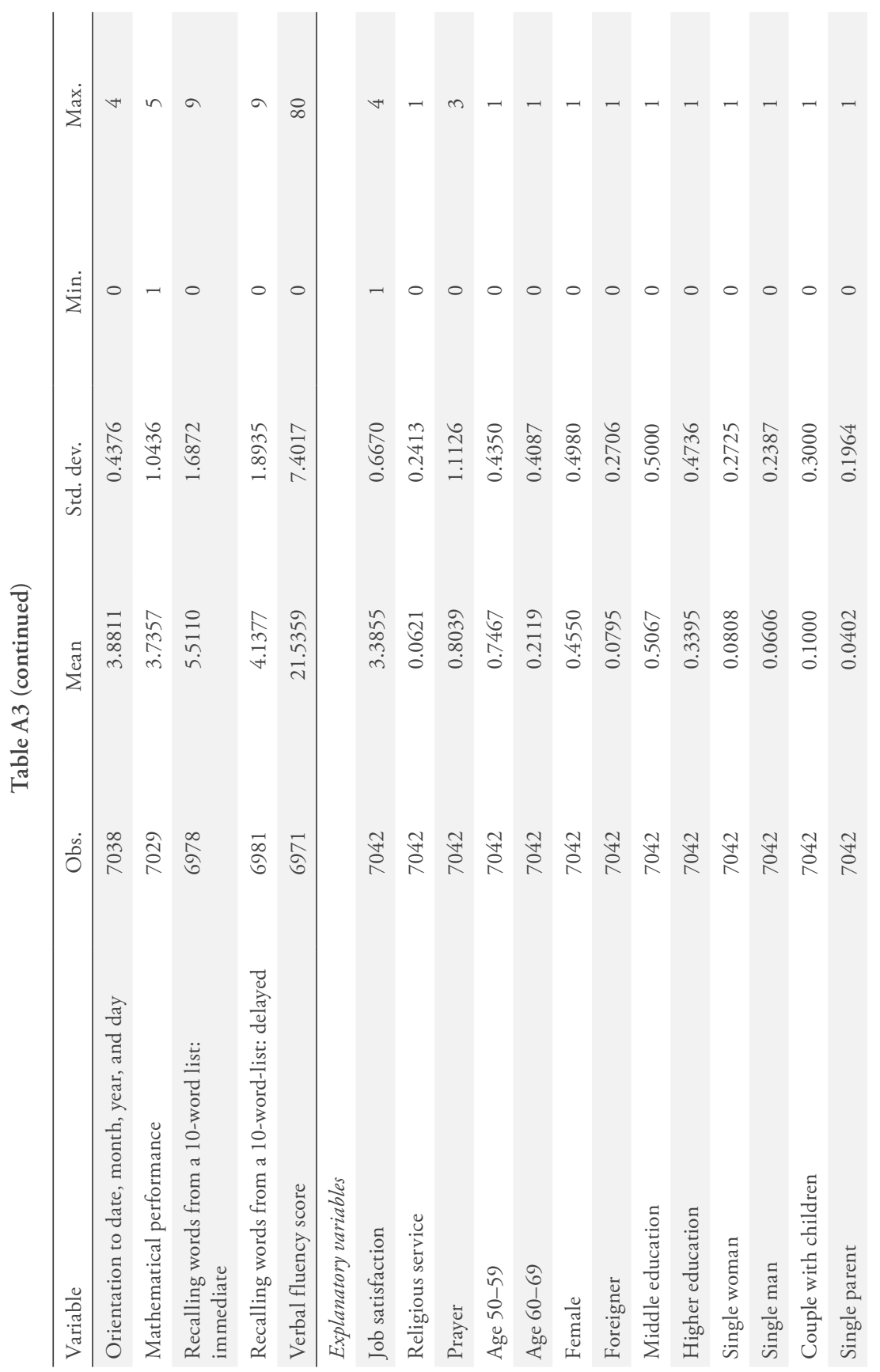




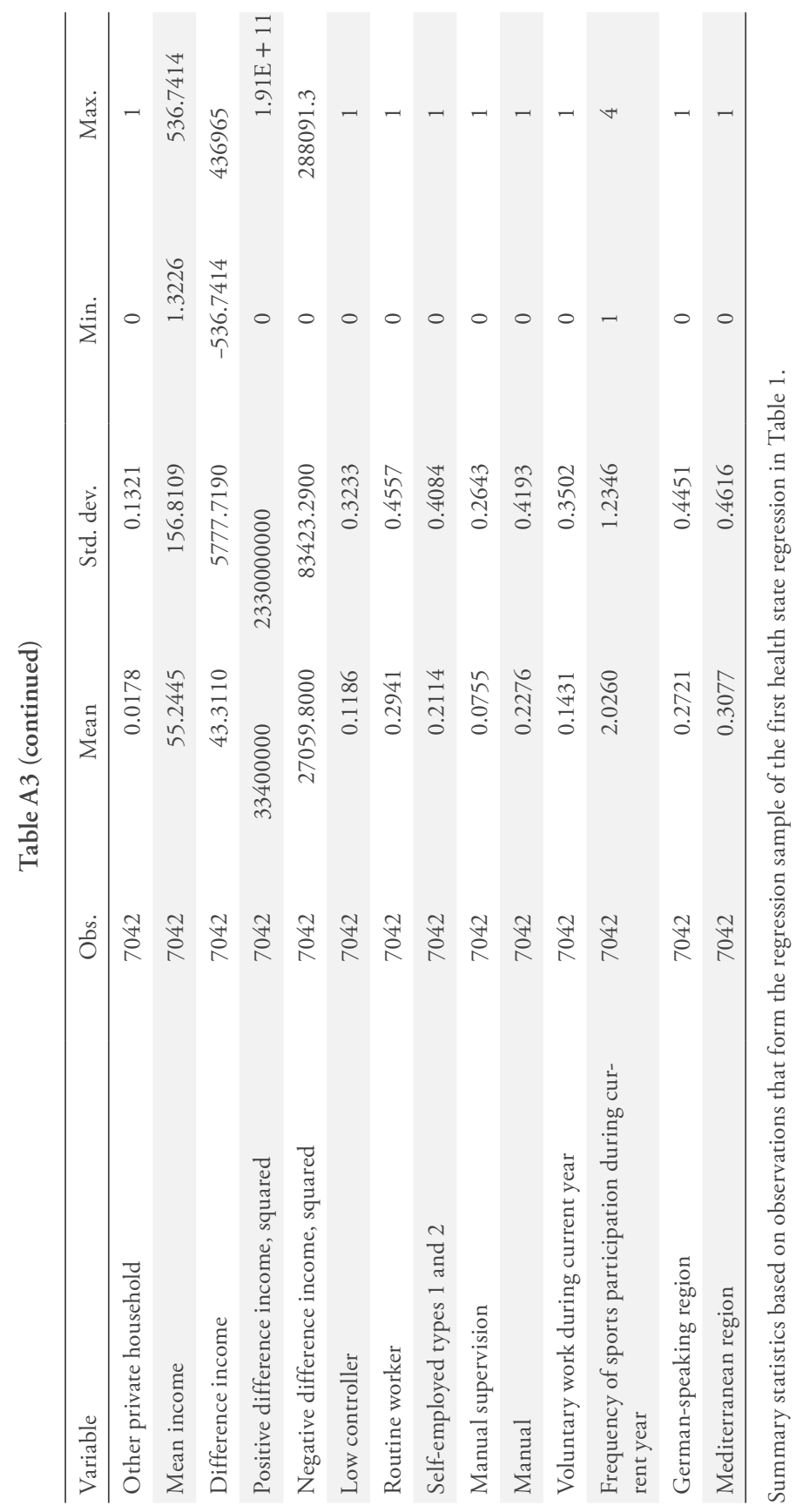




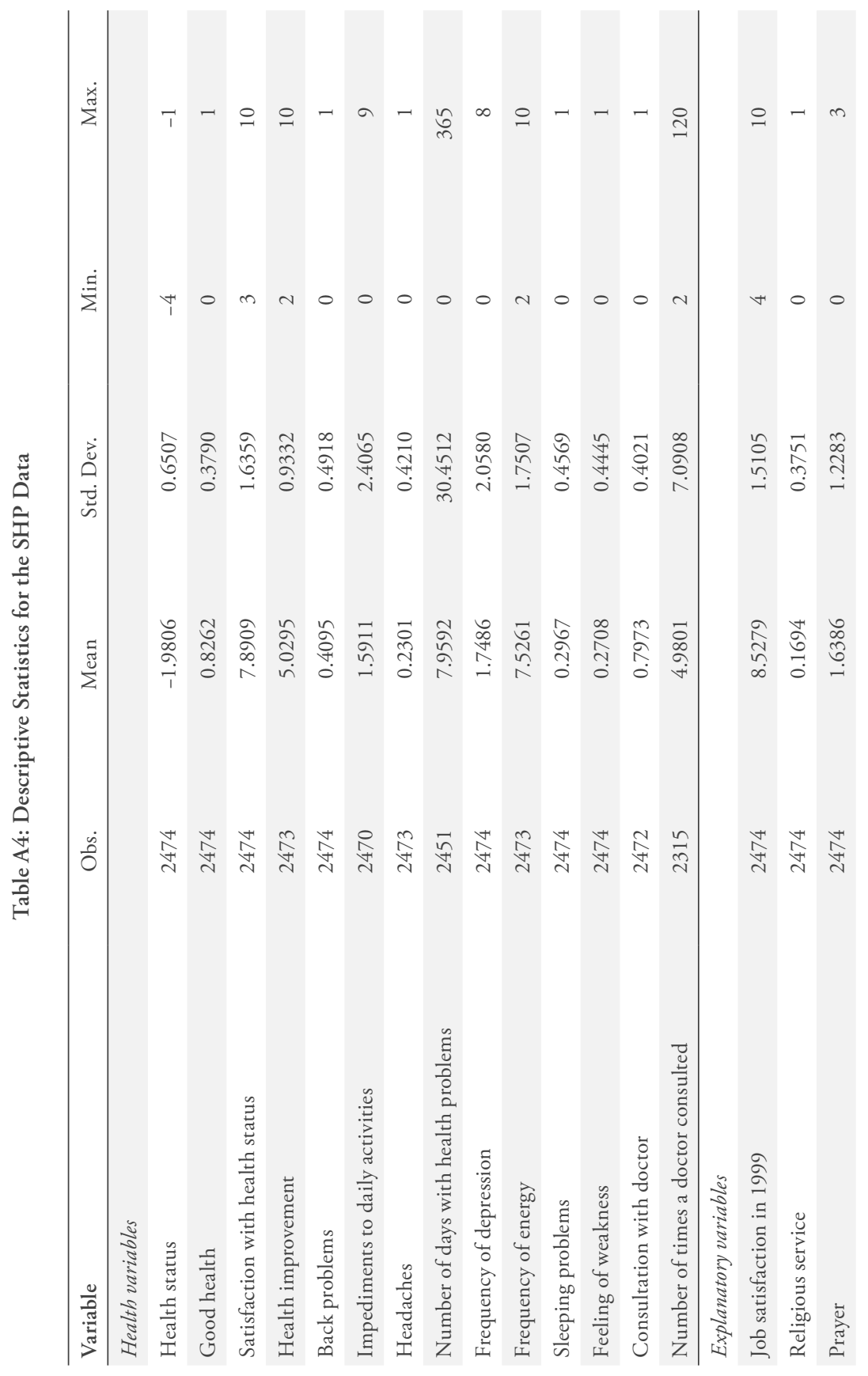




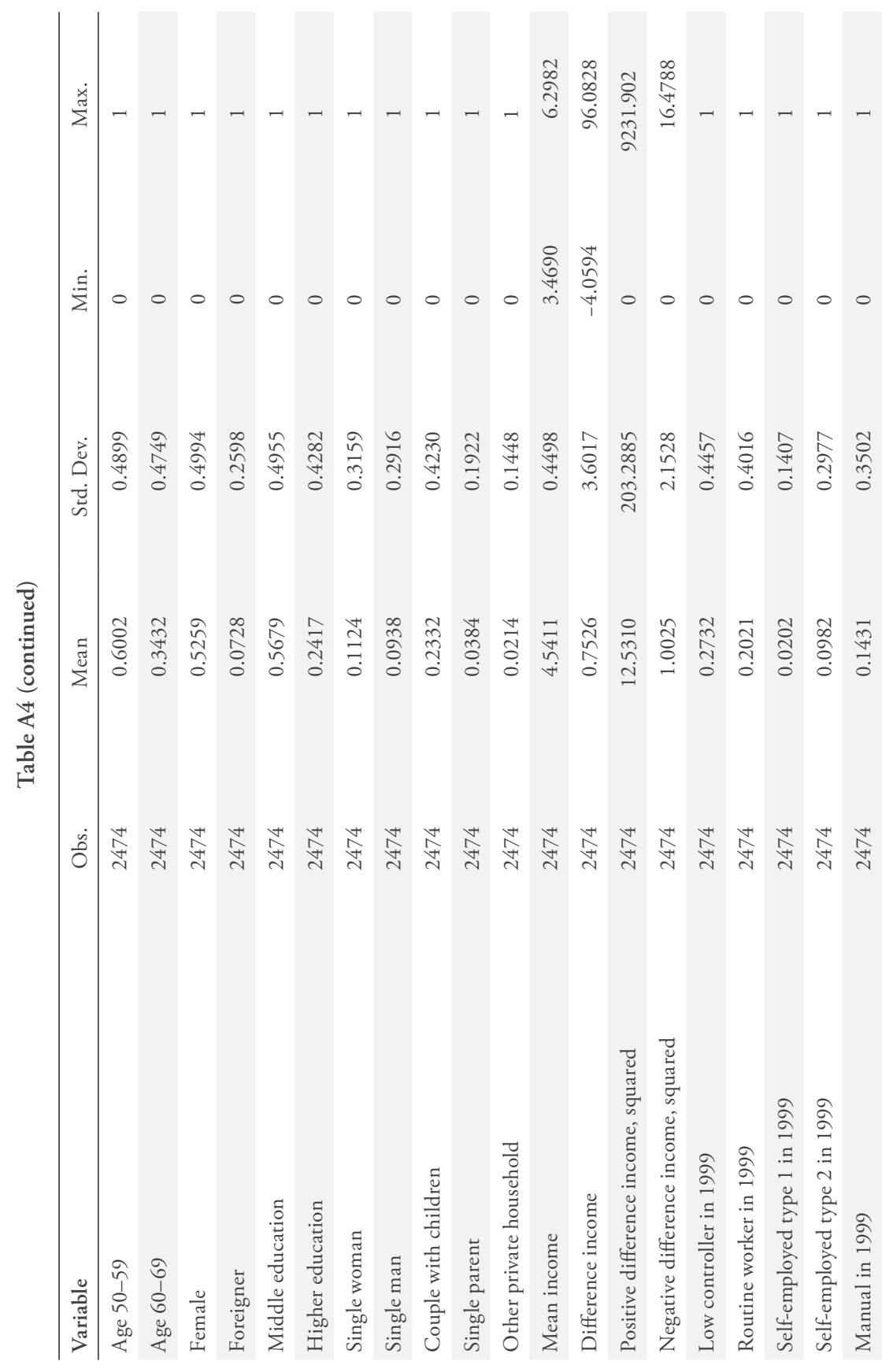




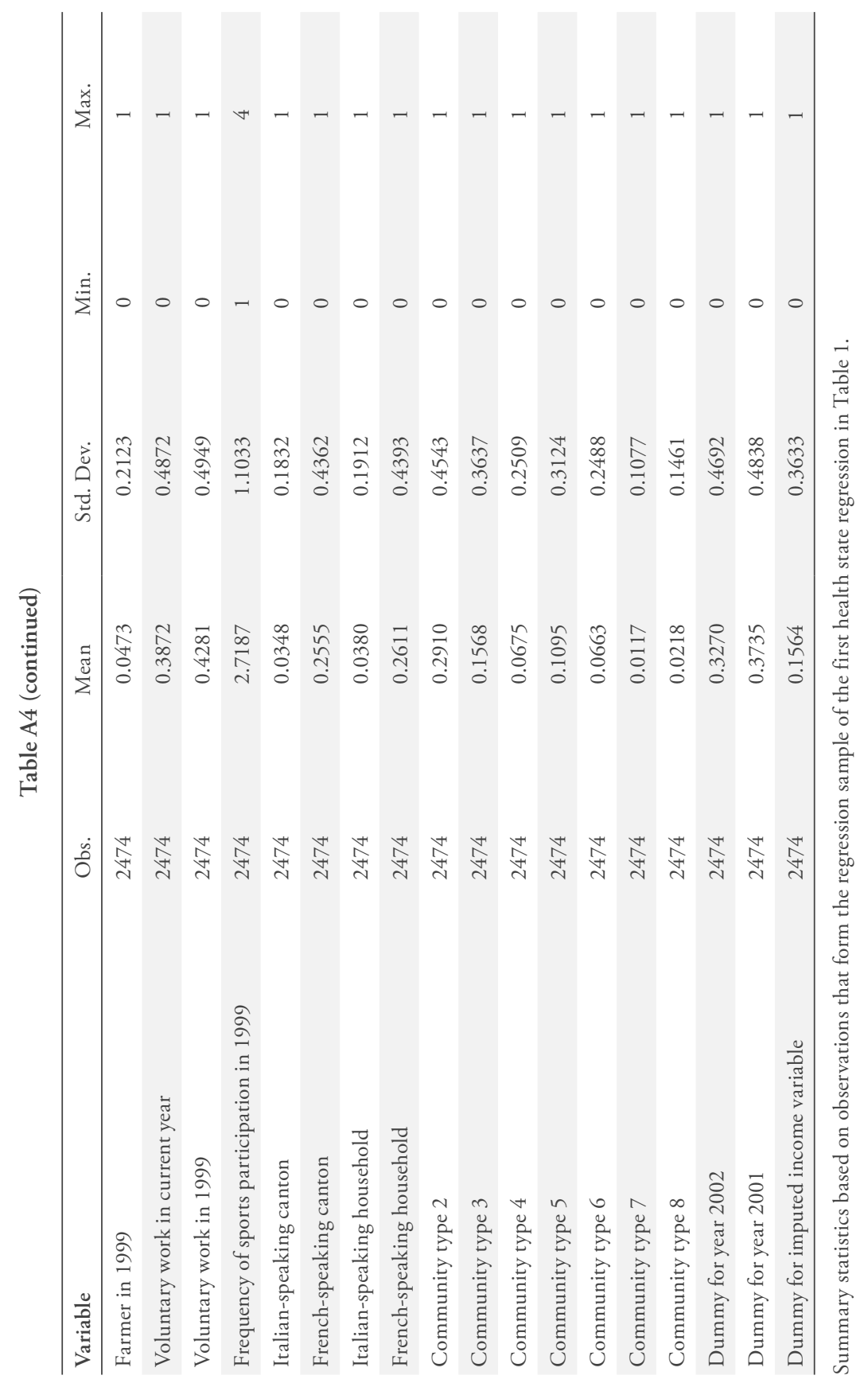




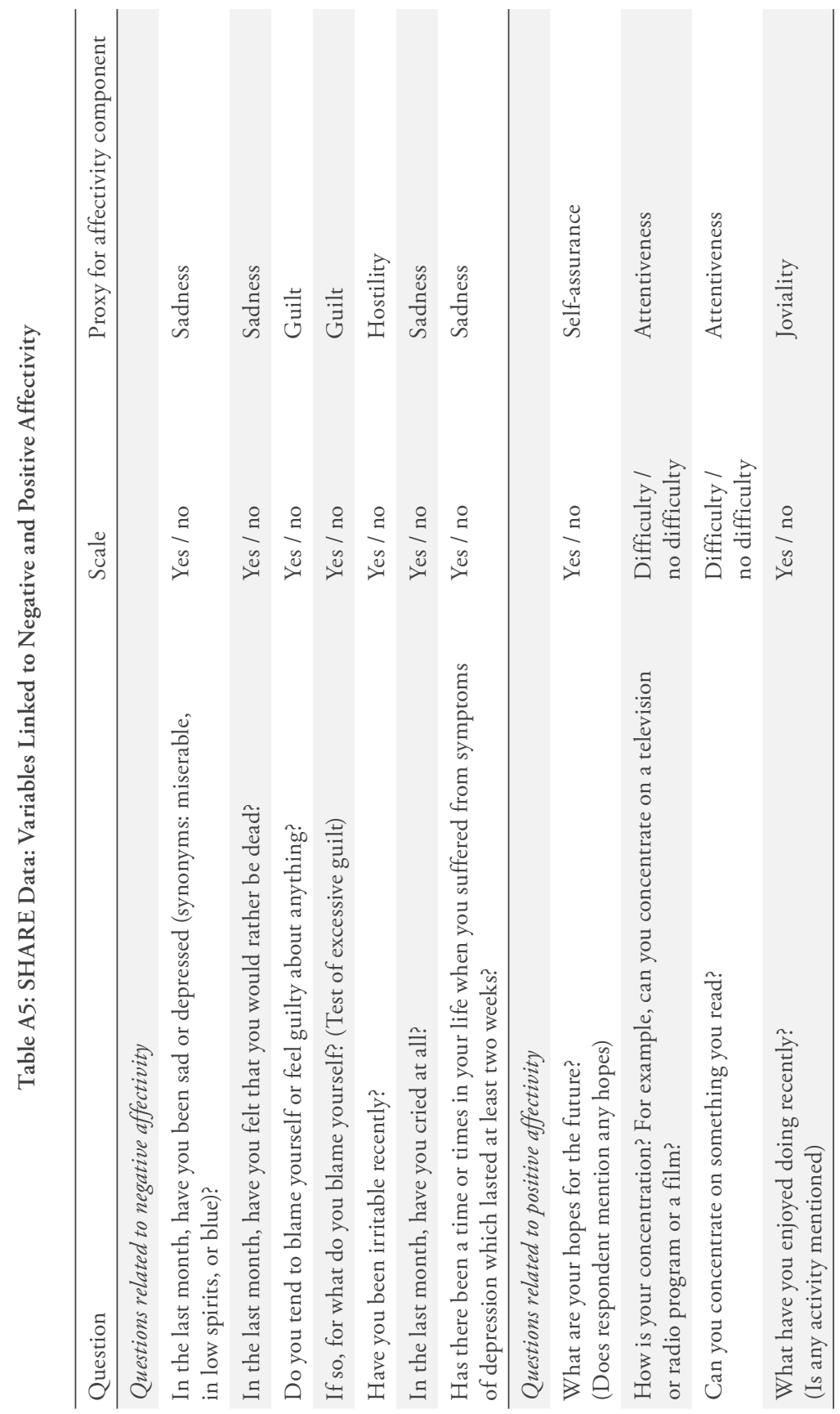




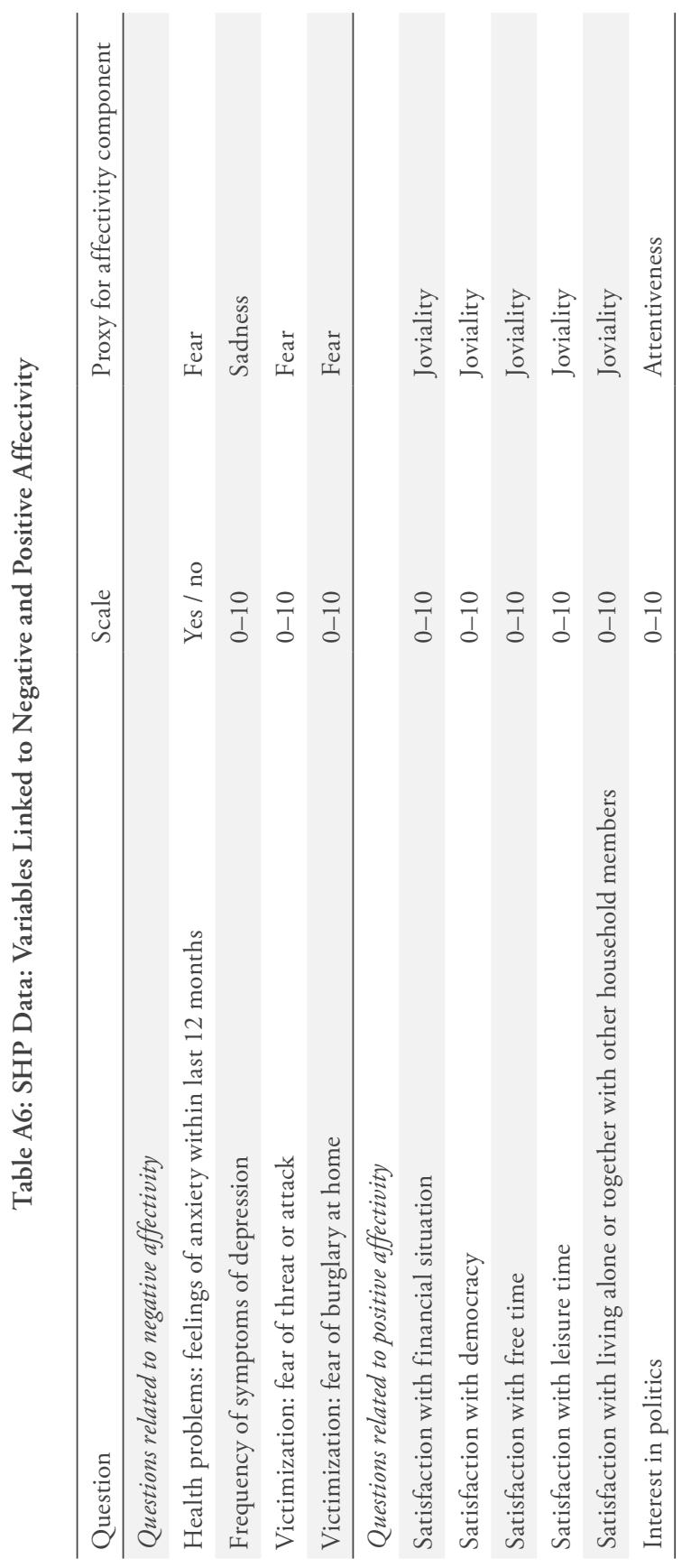




\section{References}

Almada, Stephen J., Alan B. Zonderman, Richard B. Shekelle, Alan R. Dyer, Martha L. Daviglus, Paul T. Costa, Jr, and Jeremiah Stamler (1991), "Neuroticism and Cynicism and Risk of Death in Middle-Aged Men: The Western Electric Study”, Psychosomatic Medicine, 53, pp. 165-175.

Bjørnskov, Christian, Axel Dreher, and Justina A. V. Fischer (2008), "Cross-Country Determinants of Life Satisfaction: Exploring Different Determinants across Groups in Society", Social Choice and Welfare, 30, pp. 119-173.

Bjørnskov, Christian, Axel Dreher, and Justina A. V. Fischer (2007), "The Bigger the Better? Evidence of the Effect of Government Size on Life Satisfaction around the World", Public Choice, 127, pp. 267-292.

Brebner, John, Janine Donaldson, Neil Kirby, and Lynn Ward (1995),

"Relationships between Personality and Happiness", Personality and Individual Differences, 19, pp. 251-258.

Brief, Arthur P., Michael J. Burke, Jennifer M. George, Brian S. Robinson, and Jane Webster (1988), "Should Negative Affectivity Remain an Unmeasured Variable in the Study of Job Stress?”, Journal of Applied Psychology, 73, pp. 193-198.

Burke, Michael J., Arthur P. Brief, and Jennifer M. George (1993), “The Role of Negative Affectivity in Understanding Relations between Self-Reports of Stressors and Strains: A Comment on the Applied Psychology Literature", Journal of Applied Psychology, 78, pp. 402-412.

Cheng, Helen, and Adrian Furnham (2001), "Attributional Style and Personality as Predictors of Happiness and Mental Health", Journal of Happiness Studies, 2, pp. 207-327.

Clark, Andrew E. (2001), "What Really Matters in a Job? Hedonic Measurement Using Quit Data", Labour Economics, 8, pp. 223-242.

Clark, Andrew E. (1997), "Job satisfaction and Gender: Why are Women so Happy at Work?", Labour Economics, 4, pp. 341-372.

Clark, Andrew E., Yannis Georgellis, and Peter Sanfey (1998), "Job Satisfaction, Wage Changes and Quits: Evidence from Germany", Research in Labor Economics, 17, pp. 95-121.

Clark, Andrew E., and Andrew J. Oswald (1996), "Satisfaction and Comparison Income”, Journal of Public Economics, 61, pp. 359-381.

Clark, Andrew E., Andrew J. Oswald, and Peter B. Warr (1995), "Is Job Satisfaction U-Shaped in Age?", Journal of Occupational and Organizational Psychology, 6, pp. 57-81. 
Costa, Paul T. (1987), "Influence of the Normal Personality Dimension of Neuroticism on Chest Pain Symptoms and Coronary Artery Disease", American Journal of Cardiology, 60, pp. 20J-26J.

Cramer, Daniel (1991), “Type A Behaviour Pattern, Extraversion, Neuroticism and Psychological Distress", British Journal of Medical Psychology, 64, pp. $73-83$.

Dorn, David, Justina A. V. Fischer, Gebhard Kirchgässner, and Alfonso Sousa-Poza (2008), "Direct Democracy and Life Satisfaction Revisited New Evidence for Switzerland”, Journal of Happiness Studies, 9, 2008, pp. 227-255.

Faragher, Brian E., Monica Cass, and Cary L. Cooper (2005), "The Relationship between Job Satisfaction and Health: A Meta-Analysis”, Occupational and Environmental Medicine, 62, pp. 105-112.

Fischer, Justina A. V., and Alfonso Sousa-Poza (2008), "Does Job Satisfaction Improve Health? New Evidence using Panel Data and Objective Measures of Health", Forthcoming, Health Economics, (http://dx.doi.org/10.1002/ hec.1341).

Francis, Leslie J., Laurence B. Brown, David Lester, and Ronald PhilipCHALK (1998), "Happiness is a Stable Extraversion", Personality and Individual Differences, 24, pp. 167-171.

Freeman, Richard B. (1978), "Job Satisfaction as an Economic Variable", American Economic Review, 68, pp. 135-141

Frey, Bruno S. and Alois Stutzer (2000), "Happiness, Economy and Institutions”, Economic Journal, 110, pp.918-938.

Hamermesh, Daniel S. (2001), "The Changing Distribution of Job Satisfaction”, Journal of Human Resources, 36, pp. 1-30.

Henneberger, Fred, and Alfonso Sousa-Poza (2007), with collaboration of Justina A. V. Fischer, Arbeitsplatzwechsel in der Schweiz: Eine empirische Analyse der Motive und Bestimmungsgründe, 2nd edition, Bern.

Kohler, T., N. Scherbaum, R. Richter, and S. Bottcher (1993), "The Relationship between Neuroticism and Blood Pressure Reexamined", Psychotherapy and Psychosomatics, 60, pp. 100-105.

Lonigan, Christopher J., Michael P. Carey, and A. J. Finch, Jr, (1994), "Anxiety and Depression in Children and Adolescents: Negative Affectivity and the utility of self-reports", Journal of Consulting and Clinical Psychology, 62, pp. 1000-1008.

OECD (2004), "Income-Related Inequalities in the Use of Medical Care in 21 OECD Countries", OECD Health Working Papers 2004, No. 14. 
Schmidt, Stefanie R. (1999) "Long-Run Trends in Workers' Beliefs about Their Own Job Security: Evidence from the General Social Survey”, Journal of Labor Economics, 17, pp. S127-S141.

SHARE (2004), Interviewer Project Manual of the Survey of Health, Aging and Retirement in Europe (SHARE), Main test 2004. http://www.share-project. org/new_sites/SHARE-Website/Documentation/Interviewer\%20Project $\% 20$ Manual.pdf (22 April 2008).

Sousa-Poza, Alfonso, and Andres A. Sousa-Poza (2003), "Gender Differences in job Satisfaction in Great Britain, 1991-2000, Permanent or Transitory?", Applied Economics Letters, 10, pp. 691-694.

Sousa-Poza, Alfonso, and Andres A. Sousa-Poza (2000a), "Taking another Look at the Gender/Job-Satisfaction Paradox", Kyklos, 53, pp. 135-152.

Sousa-Poza, Alfonso and Andres A. Sousa-Poza (2000b), "Well-Being at Work: A Cross-National Analysis of the Levels and Determinants of Job Satisfaction", Journal of Socio-Economics, 29, pp. 517-538.

Spector, Paul E. (1997), Job Satisfaction: Application, Assessment, Causes, and Consequences, Thousand Oaks.

Swinnerton, Kenneth A., and Howard Wial (1995), "Is Job Stability Declining in the US Economy?", Industrial and Labor Relations Review, 48, pp. 293-304.

Tsang, Mun C., Russell W. Rumberger, and Henry M. Levin (1991), "The Impact of Surplus Schooling on Worker Productivity", Industrial Relations, 30, pp. 209-228.

Wanner, Eric (1999), "Preface to the Special Issue on 'Changes in Job Stability and Job Security'”, Journal of Labor Economics, 17, pp. Siii-Siv.

Watson, David, and James W. Pennebaker (1998), "Health Complaints, Stress, and Distress: Exploring the Central Role of Negative Affectivity", Psychological Review, 96, pp. 234-254.

Watson, David, and Lee A. Clark (1994), The PANAS-X: Manual for the Positive and Negative Affect Schedule - Expanded Form, University of Iowa. http:// www.psychology.uiowa.edu/Faculty/Clark/PANAS-X.pdf (22 April 2008)

Watson, David, Lee A. Clark and Greg Carey (1988), "Positive and Negative Affect and Their Relation to Anxiety and Depressive Disorders", Journal of Abnormal Psychology, 97, pp.346-353.

Winkelmann, Rainer and Klaus F. Zimmermann (1998), "Is Job Stability Declining in Germany? Evidence from Count Data Models", Applied Economics, 30, pp. 1413-1420. 


\section{SUMMARY}

This paper evaluates the relationship between job satisfaction and subjective and objective measures of health of workers over 50 using the Swiss Household Panel (SHP) and cross-sectional data from the Survey on Health, Ageing and Retirement in Europe (SHARE). Methodologically, we address problems of (a) crosssectional causality and (b) absence of objective measures of physical health and intellectual ability. We find a positive link between job satisfaction and various self-report health measures and intellectual ability, but not for physical health. Further analysis with the SHP indicates that job satisfaction serves as transmission channel of working conditions, prior health state and affective mental state for most self-report measures, while for specific health problems such as depressive states and problems with the back a direct beneficial effect of job satisfaction remains. 